\title{
Solvency Risk Premia and the Carry Trades*
}

\author{
Vitaly Orlov ${ }^{\dagger}$ \\ Swiss Institute of Banking and Finance (s/bf-HSG), University of St. Gallen, Unterer Graben 21, CH-9000 \\ St. Gallen, Switzerland
}

\begin{abstract}
This paper shows that currency carry trades can be rationalized by the time-varying risk premia originating from the sovereign solvency risk. We find that solvency risk is a key determinant of risk premia in the cross section of carry trade returns, as its covariance with returns captures a substantial part of the cross-sectional variation of carry trade returns. Importantly, low interest rate currencies serve as insurance against solvency risk, while high interest rate currencies expose investors to more risk. The results are not attenuated by existing risks and pass a broad range of various robustness checks.
\end{abstract}

JEL classifications: F31, G15

Keywords: Solvency Risk; Carry Trades; Risk Premia

* The author is grateful for the comments and suggestions of Richard Levich (discussant), Matti Suominen (discussant), Jacobs Heiko (discussant), Ming-Hua Liu (discussant), Darya Yuferova (discussant), Rita Biswas (discussant), Paul Söderlind, Johan Knif, Angelo Ranaldo, Nikolai Roussanov, Mikko Leppämäki, Marku Kaustia, Maria Gonzalez-Perez, Peter Nyberg and participants of the 14th Paris December Finance Meeting, the 2017 EFA Annual Meeting, the 29th Australasian Finance and Banking Conference, the 15th INFINITI Conference on International Finance, IFABS 2016 Barcelona Conference, and seminar participants at the GSF workshop (Aalto University), NFN workshop (NHH), CUNEF, University of Vaasa, and University of St Gallen. The paper was partially written while V. Orlov was a visiting scholar at the Columbia Business School. Author gratefully acknowledges financial support from the OP-Pohjola Group Research Foundation (grant 201500087) and Marcus Wallenberg foundation.

† Corresponding author. Tel.: +41 71224 7003. E-mail address: vitaly.orlov@ unisg.ch (V. Orlov). 


\section{Introduction}

This paper studies risk-return characteristics of the currency carry trade strategy that is implemented by borrowing in a low interest rate currency and subsequent investing in a high interest rate currency. Provided that uncovered interest parity holds, investment currency depreciation offsets the interest rate differential (forward premium) and returns to carry are zero. In fact, the opposite holds true and the long-standing phenomena of currency carry trade has its roots in persistent deviations from uncovered interest parity and empirical rejection of the forward rate unbiasedness hypothesis; that is, the forward premium is an apparent biased predictor of a future spot exchange rate change (Fama, 1984). These feasible discrepancies in macroeconomic parity conditions give rise to positive average historical returns of the carry trade strategy and the forward premium puzzle.

Seeking an explanation of the forward premium puzzle and carry trade returns has been an important topic in international finance for over three decades, the debate being initiated by Hansen and Hodrick (1980, 1983) and Fama (1984). The main avenue for research perceives the carry trade returns as a compensation for a common risk. Therein currencies are prone to deliver low/high carry trade returns in bad/good times due to persistent heterogeneity in risk exposures between investment and funding currencies. Several recent studies suggest a number of possible explanations for observed patterns of heterogeneous risk exposures (see, e.g., Lustig, Roussanov, and Verdelhan, 2011; Menkhoff, Sarno, Schmeling, and Schrimpf, 2012; Lettau, Maggiori, and Weber, 2014; Della Corte, Riddiough, and Sarno, 2016; and others which we discuss in the following section). Overall, the cumulative evidence points to time-varying risk premia as the pervasive source of the carry trade returns and to the forward premium puzzle not being without costs. Nonetheless, the identification of an appropriate risk premia that explains the carry trade profitability remains an ongoing debate. This paper provides new evidence in favor of sovereign solvency being a potential source of risk in currency market. 
Despite the abundance of research that strives to identify a convenient time-varying currency risk premia, there is little research on the relation of sovereign solvency risk to exchange rates and currency market. Notably, several recent studies provide mixed evidence on the marginal value of sovereign CDS spreads in interpreting the forward premium puzzle around the financial crisis dates. Hui and Chung (2011) show that CDS implied information is transmitted to the currency options and, consequently, to the Euro crash risk probability. Coudert and Mignon (2013) find the crash-consistent behavior of emerging currencies, such that default risk contributes to higher returns during expansion and massive losses during market turmoil, but no evidence on reconciliation of the forward premium puzzle using CDS spreads emerges from the cross-section of the most common carry trade currencies. In contrast, Della Corte, Sarno, Schmeling, and Wagner (2016) find evidence of currency depreciation as well as rise in volatility due to contemporaneous increase in CDS spread, and point out the cross-sectional pricing ability of sovereign risk for the test portfolios drawn from the set of developed and emerging currencies. This study goes beyond earlier research on solvency risk, being the first paper that (i) abstracts from the market measures of country's creditworthiness and relies on fundamentals; (ii) covers a long time period and large cross-section of up to 48 currencies; and (iii) provides evidence of sovereign solvency pricing ability in various crosssections, including the one of developed countries.

This paper contributes to current debate by revealing a new economic-based time-varying risk premia in the currency market that depends upon a country's solvency. We argue that the financial capacity of the economy, captured by the solvency measures, incites the differences in average carry trade excess returns. In other words, the profitability of currency carry trades can be rationalized by the time-varying risk premia that originate from the sovereign solvency risk. Consistently, we find that high interest rate currencies demand a higher risk premium, as 
they deliver low carry trade returns at times of high solvency risk, therefore exposing investors to more risk, whereas low interest currencies are a hedge against the solvency risk.

This paper proposes a new risk-adjusted version of uncovered interest parity (UIP). Bridging the macroeconomic concepts of debt elastic interest rate and risk premium associated with lending to the economy, we lay out a UIP that is disturbed by country-specific risk premia given by the increasing convex function of the debt service capacity of the economy. Therein, time-varying solvency risk premia offset the disparity between actual and expected exchange rate, establishing equilibrium. This provides a simple and intuitive risk-based view on exchange rate determination by a risk premium varying in the solvency of the economy.

The empirical findings of the paper indicate that solvency risk preserves the substantial power to explain the cross-section of carry trade returns. This paper introduces a new, solvency-based, risk factor and show that its covariance with returns accounts a large part of the variation in the cross-section of carry trade returns. Our empirical approach relies on much of the recent literature (Lustig, Roussanov, and Verdelhan, 2011; and Ready, Roussanov, and Ward, 2016). We perform portfolio sorts on forward discounts and the solvency measure, identify risk factor as the returns on zero-cost long-short strategy between the last and first solvency-sorted portfolios and label it IMS, for indebted-minus-solvent economies. The IMS factor explains the substantial part of the cross-sectional variation in carry trade portfolios, exhibiting monotonically increasing factor loadings and significant prices of risk, consistent with risk premia explanation. Moreover, the factor is empirically powerful in various model specifications and sample splits, prices different test assets, stands out horse races with other currency-specific risk factors, robust against an alternative funding currency (the Japanese Yen) and alternative solvency measure specifications, and passes several other robustness checks. Taken collectively pointing to the solvency risk factor being an effective tool for pricing the cross-section of carry returns. 
This study contributes to the literature in several important ways. First, the empirical findings of this paper lend additional support to the risk-based view of the forward premium puzzle. In line with findings of studies, such as those of Hansen and Hodrick (1980), Fama (1984) and Engel (1996), this paper shows that the apparent slump of UIP can be interpreted as a compensation for risk. Second, this paper extends the findings of prior research searching for an appropriate time-varying currency risk premium that rationalizes returns to the carry trade strategy (see, e.g., Lustig and Verdelhan, 2007; Lustig, Roussanov, and Verdelhan, 2011; Menkhoff, Sarno, Schmeling, and Schrimpf, 2012; Lettau, Maggiori, and Weber, 2014; and Ready, Roussanov, and Ward, 2016). This paper identifies a new source of risk premia and shows that currency carry trades can be comprehended as a compensation for sovereign solvency risk, supporting the previous evidence of relation between currency excess returns and sovereign risk (see, e.g., Della Corte, Sarno, Schmeling, and Wagner, 2016). Third, this study adds to the prior literature on a country's creditworthiness as an explanation of currency carry trades (see, e.g., Hui and Chung, 2011; Coudert and Mignon, 2013; and Huang and MacDonald, 2014), while addressing the critique of Longstaff, Pan, Pedersen, and Singleton (2011) of applying market measures to assess sovereign financial solvency.

The remainder of the paper is organized as follows. In Section 2 we provide an overview of the essential theories behind carry trade, initiate the discussion of our main solvency measure, and derive risk-adjusted UIP. Section 3 is dedicated to descriptions of the data, portfolios, and risk factors, and supplying descriptive statistics. The empirical approach and asset pricing tests are discussed in Section 4, followed by a review of the main empirical evidence on solvency risk in Section 5. The results of the robustness checks are presented in Section 6. Section 7 concludes the paper. This paper also incorporates an Appendix that provides supplementary results. Finally, the results of additional robustness checks are presented in the Internet Appendix. 


\section{Background Ideas}

In this section we present the theoretical background and the analytical framework underpinning this paper. We start with an overview of the existing literature and focus on rational risk premia interpretations. Next, we specify our measure of creditworthiness of the economy, and the rationale behind it. Finally, we consider the highly indebted economy and introduce the sovereign risk premium through the specification of an upward sloping foreign debt supply function and present risk-adjusted version of UIP.

\subsection{Essential theory}

The exercise of the carry trade strategy is firmly related to the forecasting shortcomings of forward rates, which is commonly referred to as the forward premium anomaly. Specifically, forward premia, contrary to the unbiasedness hypothesis, fall short in predicting future spot exchange rate appreciation. If forward rates were unbiased, the carry trade returns would be indistinguishable from zero. The explanation of positive historical carry trade payoffs has become a cornerstone of understanding the forward premium puzzle.

Perhaps the major avenue for research to comprehend the forward premium puzzle is the identification of a convenient time-varying risk premia. This stream of literature strives to provide a risk-based explanation for the puzzle through defining carry trade returns as a compensation for an appropriate risk. Building on the classic contribution of Hansen and Hodrick (1980), Fama (1984) brings the discussion to the efficient markets framework and shows the apparent failure of UIP across various currencies and time periods, which manifests in negative estimates of the slope parameter of the so-called Fama-regression. Importantly, the 
residual component of that regression is interpreted as the time-varying currency risk premium that rationalizes returns to the carry trade strategy. ${ }^{1}$

The inability of conventional risk factors to indisputably reconcile the puzzle, manifested in Burnside, Eichenbaum, and Rebelo (2011), has spurred a number of original currency-specific interpretations. Lustig, Roussanov, and Verdelhan (2011) adopt a Fama and French (1993) style approach to forward-sorted currencies and find heterogeneity in exposures to common risks across portfolios, related to rational risk premia. In a similar vein, Menkhoff, Sarno, Schmeling, and Schrimpf (2012) demonstrate that global currency market volatility shocks exert a compelling pricing power in the cross-section of carry trade returns. Mancini, Ranaldo, and Wrampelmeyer (2013) and Karnaukh, Ranaldo, and Söderlind (2015) reveal the substantial role of currency market liquidity in explaining the carry trade strategy payoffs. Findings in his paper complement the aforementioned risk-based explanations, and suggest an original solvency-based interpretation of currency risk premia.

This paper is also related to the literature that strives to find fundamental economic differences across countries that could explain the heterogeneity in risk exposures, e.g., Ready, Roussanov, and Ward (2016) in the model of equilibrium show that heterogeneity in excess returns between high and low interest rate currencies arises from the differences in composition of the trade balance. Perhaps even more related to current study, Della Corte, Riddiough, and

\footnotetext{
${ }^{1}$ Alternatively, the existence of that residual component can be taken as evidence of market inefficiency (see, e.g., Bilson, 1981; Froot and Thaler, 1990; and Burnside, Han, Hirshleifer, and Wang, 2011). Other studies suggests that uncertainty about a future shifts in regimes results in biased measures of market expectations and, hence, a skewed distribution of forecast errors (see, e.g., Krasker, 1980; Kaminsky, 1993; Evans, 1996; and Burnside, Eichenbaum, Kleshchelski, and Rebelo, 2011). Finally, several studies focus on the interpretation of the puzzle from the microstructure point of view, finding evidence of order flow related determinants of exchange rates (see, e.g., Lyons, 2001; and Evans and Lyons, 2002).
} 
Sarno (2016), in connection with the theoretical model of Gabaix and Maggiori (2015), show that global imbalances in countries' foreign liabilities capture a large part of cross-sectional variation in currency excess returns. In particular, authors perform a two-way sort using the net foreign asset position-to-output and the proportion of external liabilities denominated in domestic currency. This provides an impressive pricing ability of a risk factor that is long (short) in currencies of debtor (creditor) nations with foreign (domestic) denominated liabilities, connecting countries' external imbalances and currency risk premia, as predicted in Gabaix and Maggiori (2015). Relative to our paper, this study has a different focus, and does not provide evidence on how sovereign solvency risk relates to currency risk, as (i) sorting on global imbalances does not capture countries' creditworthiness; ${ }^{2}$ and (ii) gross $/$ net foreign liability measures, by construction, does not accurately reflect information on countries' indebtedness. ${ }^{3}$

Although, the research on links between exchange rates, currency anomalies and solvency risk is exiguous, there is strong anecdotal evidence that severe currency crashes follow the actual sovereign defaults (see, e.g., Reinhart, 2002; Mano, 2013). Moreover, Della Corte, Sarno, Schmeling, and Wagner (2016) indicate a strong association between default

\footnotetext{
${ }^{2}$ For example, over the period from 1990 to 2004, most common carry currencies, like, JPY, AUD and NZD
} earn a corresponding average return of $-1.14,1.94$ and 3.93 percent. However, the average proportions of external liability denominated in domestic currency (denoted $l d c$ in DRS, 2016) over the same period are 50.57, 62.14, and 47.05 percent, respectively, thus are counter-intuitive. At the same time, total foreign liabilities-to-GDP measures are 42.44, 100.88 and 136.37, reflecting that indebted countries earn higher return. Same holds for other solvency measures. Data is from Lane and Shambaugh (2010) and is kindly provided on Philip Lane's webpage.

${ }^{3}$ According to the IMF, foreign liabilities, regardless of the currency they are in, include not only external debt, but also foreign liabilities that do not convey a payment obligation, e.g., equity securities of domestic companies and investment funds held by foreign investors, capital participations by foreign direct investors in domestic companies, as well as contingent liabilities from derivative trades. 
expectations (solvency risk) and currency fluctuations as well as the higher moments of exchange rates. We find that common carry currencies require high risk premium, as they deliver low carry trade returns at times of high solvency risk, while funding currencies are a hedge against the solvency risk. This relates our paper to Gomes and Schmid (2012), who show credit risk produces a countercyclical risk premium, capturing good and bad states of the economy and to studies like, Lettau, Maggiori, and Weber (2014) and Jurek (2014), who argue that investment currencies exhibit large beta loadings conditional on the state of the market, particularly in times of market downturn. Daniel, Hodrick, and Lu (2017), however, find no evidence of downside risk in dollar-neutral carry trades. Finally, Ranaldo and Soderlind (2010) find that low interest rate currencies serve as a hedge against market turmoil, appreciating when the aggregate risk is high.

\subsection{Solvency measure}

In this paper, we rely on the fundamental measures of the financial solvency of the economy. The macroeconomics literature has a long history of investigating optimal borrowing. The first study to assume imperfect capital markets for debt is that of Bardhan (1967) who suggested that cost of debt increases at the aggregate level of foreign debt. Diamond (1965) investigates the effects of the stock of external debt on the economy dynamics with a neoclassical growth model. More recent studies also investigate equilibrium dynamics with debt level elastic interest rates (see, e.g., Obstfeld, 1982; Eaton and Turnovsky, 1983; Bhandari, Haque, and Turnovsky, 1990; and Schmitt-Grohe and Uribe, 2003). Another way to incorporate the idea of imperfect markets is to consider the measure of a country's ability to service the outstanding debt, as creditworthiness of the economy can be a function of more than just a level of foreign debt. Otani and Villanueva (1988) model the risk premium charged on foreign debt as a function of the debt-to-export ratio. Cohen and Sachs (1986) and Escudé (2013) assume that 
risk premia depend on a country's ability to cover the debt as represented by debt-to-output or capital ratio.

In this paper we assume risk premium is a function of financial solvency of the economy, defined by either a ratio of foreign debt to economy's earning ability (henceforth, the solvency measure), or a ratio of balance of the current account to the estimated aggregate of total exports of goods and services, or aggregated financial solvency index. Risk premium is then represented by an increasing convex function of one of these measures. In the most of our analysis, we consider external debt service capacity measured by the gross foreign debt-tooutput ratio as a measure of solvency of the country, expressed as:

$$
\gamma_{t}^{i}=\frac{\text { Gross Foreign Debt } t_{t}^{U S D}}{G D P_{t}^{U S D}}
$$

where we quantify the ability of the economy $i$ to pay external debt by expressing gross foreign debt as the percentage of gross domestic product in period $t$. To ensure comparability between countries we convert both quantities into U.S. dollars at an average exchange rate for that period. The change in this measure can be altered by variations in the level of foreign debt and/or a shift in the output measure. This measure is empirically quantifiable and within our framework indicates the level of solvency of the economy, reflecting the degree to which the country bears the risk. Later in the paper we describe the data collection process and consider alternative ways to quantify the financial competence of the economy.

Importantly, we abstract from the market measures of country's creditworthiness and rely on fundamentals. This allows us to obtain large cross-section of currencies with the longest possible time span in order to take a classic SDF route in explaining the returns to currency speculation. Along with that, there is also evidence that market-based measures (CDS spreads) do not offer a true prediction of financial distress. Longstaff, Pan, Pedersen, and Singleton 
(2011) demonstrate that sovereign CDS spreads are plagued by time-varying systemic risk, global risk premia and other global and regional economic forces, while exhibiting almost no evidence of sovereign-specific credit risk premia. Ang and Longstaff (2013) also show that sovereign CDS spreads do not in fact capture country-specific information, but are rather related to market-wide factors. Capitalizing on that evidence, this study considers the fundamental measures of the financial competence of the economy.

\subsection{UIP with the Solvency Risk disturbance term}

As noted earlier, the key assumption of the paper is that the domestic economy does not face a perfectly elastic supply of debt, but rather an upward sloping supply curve for debt. Kharas (1983) and Kharas and Shishido (1986) show that this supposition appears to be realistic as repayment commitments for various reasons are not always made on time. Thus, foreign lenders are likely to form expectations about the ability of an economy to repay debt, requiring a risk premium over the international interest rate for lending to the economy. Merging the concepts of debt elastic interest rate and risk premium associated with lending to the economy, the interest rate charged on foreign debt is:

$$
i(y)_{t}=i_{t}^{*}+v(y)_{t}, \quad v^{\prime}>0, \quad v^{\prime \prime}>0
$$

where the interest rate $i(y)_{t}$ faced by domestic agents in time $t$ depends on the level of world interest rate $\left(i^{*}\right)$ and the country-specific risk premium $(v(y))$, which varies with the debt service capacity of the economy as measured by solvency measure. Sovereign risk premium is assumed to be an increasing and convex function $\left(v \equiv 1+\bar{v}>1, v^{\prime \prime}>0\right)$, so that the interest rate grows at an increasing rate with the level of indebtedness of the economy until a predetermined borrowing constraint is reached. Thus, the risk premium inversely related to the 
debt service capacity of the economy. Rewriting equation (2) in a form that represents domestic rate provides the following expression that households must deal with:

$$
\left(1+i_{t}\right)=\left(1+i_{t}^{*}\right) v(y)_{t}
$$

In this setup, a change in an endogenous risk premium associated with the financial capacity of the domestic economy reflects country-specific borrowing constraints. Importantly, we derive the risk-adjusted UIP of the following form: ${ }^{4}$

$$
\left(1+i_{t}\right)=\left(1+i_{t}^{*}\right) v\left(\gamma_{t}\right) E_{t}\left(\delta_{t+1}\right)
$$

The result is a UIP that is disturbed by the endogenous risk premium given by the increasing convex function of the debt service capacity of the economy as measured by the foreign debtto-output ratio. Independent of the presence of the risk premium and under the rational expectation assumption, UIP stipulates the exchange rate $\left(\delta_{t+1}\right)$ depreciation (appreciation) equivalent to the interest rate differential. Conversely, equation (4) suggests the risk-adjusted version of UIP such as the time-varying risk premium $\left(v\left(\gamma_{t}\right)\right)$ balances the difference between the actual and expected exchange rate. Importantly, since the risk premium is plausibly assumed to be an increasing and convex function such a parity condition predicts that interest rate differentials should increase in the solvency measure, followed by higher excess returns. In addition, a positive change in the interest rate differential can produce an even larger change

\footnotetext{
${ }^{4}$ We provide the description of the setup, the detailed derivation of UIP disturbed by the solvency risk premia
} in the Internet Appendix. 
in the risk premium, as it results in an upward shift in the increasing convex risk premium function.

Summing up, the resulting risk-adjusted equilibrium parity condition of currency pricing implies: First, highly indebted countries have higher interest rates and forward discounts on average than solvent countries; second, an indebted currency earns positive expected return, that increases in the solvency measure; third, the interest rate differential and the solvency currency risk premium both increase in measures of an economy's financial capacity; and, finally, currency of an indebted country is risky, as it appreciates in good times and depreciates in bad times. Overall, this section provides an intuitive risk-based view of exchange rate determination with risk premium varying with the debt service capacity of the economy. Notably, we propose a new version of risk-adjusted UIP, and outline the abovementioned qualitative predictions, which we also evaluate empirically.

\section{Data, Currency Portfolios and Risk factor building}

\subsection{Currency data}

The full sample of this study consists of 48 currencies. For each currency we collect endof-month data of spot exchange rates and of one-month forward exchange rates from Barclays and Reuters via Datastream. The countries in the sample are those of: Australia, Austria, Belgium, Brazil, Bulgaria, Canada, Croatia, Cyprus, Czech Republic, Denmark, Egypt, Euro area, Finland, France, Germany, Greece, Hong Kong, Hungary, India, Indonesia, Ireland, Israel, Italy, Iceland, Japan, Kuwait, Malaysia, Mexico, Netherlands, New Zealand, Norway, Philippines, Poland, Portugal, Russia, Saudi Arabia, Singapore, Slovakia, Slovenia, South Africa, South Korea, Spain, Sweden, Switzerland, Taiwan, Thailand, Ukraine, United Kingdom. The sample coverage for spot and forward rates spans January 1985- December 
$2014 .^{5}$ All of the rates are expressed as units of foreign currency per one U.S. dollar. Our analysis is executed on a monthly frequency.

Also, we consider a subsample of spot and forward rates of the ten most actively traded currencies, henceforth referred to as developed countries. These ten counties are: Australia, Canada, Denmark, Germany/Euro area, Japan, New Zealand, Norway, Sweden, Switzerland, United Kingdom. We merge the time series on forward discount and excess returns of the German Deutschemark prior to 1999 and those for the Euro, while taking German data on solvency measures in the post-euro introduction period. To further assess robustness, we repeat the empirical analysis with data samples identical to Lustig, Roussanov, and Verdelhan (2011) (37 currencies) and Burnside, Eichenbaum, and Rebelo (2011) (20 currencies). ${ }^{6}$

In this study we estimate currency excess returns from the U.S. investor point of view, so that the U.S. dollar is considered to be a domestic currency. In the empirical analysis we operate with logarithms, denoting $s$ and $f$ as $\log$ spot and log forward rate, respectively. We rely on the relation implied by covered interest parity, where the interest rate differential is approximately equal to the $\log$ forward discount $\left(i_{t}^{*}-i_{t} \approx f_{t}-s_{t}\right)$, spot exchange rate appreciation or depreciation is defined by $s_{t+1}-s_{t}$ and the currency excess return is then defined such that $r_{t+1}=i_{t}^{*}-i_{t}-s_{t+1}+s_{t} \approx f_{t}-s_{t+1}$

${ }^{5}$ Burnside, Eichenbaum, and Rebelo (2011) and Menkhoff, Sarno, Schmeling, and Schrimpf (2012) extend their datasets back to 1976 by complementing BBI and Reuters data (available from October 1983) with historical Reuters data quoted against the British Pound, resulting in the longest possible time series of currency data. Lustig, Roussanov, and Verdelhan (2011) operate with the sample that starts in 1983. However, data on only nine currencies is available prior to 1985 and, as noted in Ready, Roussanov and Ward (2016), major carry trade currencies were undergoing transition to a floating exchange rate regime before 1985 . Motivated by this and due to the availability of data on solvency measure our sample period begins in 1985 .

${ }^{6}$ Results are unreported, but available upon request. 


\subsection{Solvency data}

In our empirical analysis, we first consider the ratio of foreign debt to GDP as a measure of the indebtedness of the economy. Specifically, we collect the estimated foreign debt and estimated GDP at the end of each year for each country in our sample from International Financial Statistics, subsequently putting quantities at an equal footing by converting estimates into U.S. dollars at an average exchange rate for the year in question. ${ }^{7}$ In this paper, foreign debt comprises all foreign liabilities that require payments of principal and/or interest by the debtor, therefore constituting payment obligations for an economy. ${ }^{8}$ The data period is matched with the one for currency data and spans the period December 1984- December 2014.

Table 1 presents average monthly estimates for forward discounts, excess returns and average values of solvency measure for the most actively traded currencies (sample of developed countries) over the sample period. Notably, countries with high average excess returns are associated with high values of forward discount (high interest rate differentials), which is consistent with the evidence from the previous studies (see, e.g., Brunnermeier, Nagel and Pedersen, 2009; Lustig, Roussanov, and Verdelhan, 2011). Importantly, we observe a remarkable heterogeneity in the average solvency measures across countries aligning with the carry trade returns and forward discounts. Countries with a high foreign debt-to-GDP ratio also

\footnotetext{
${ }^{7}$ Converting of solvency measure to USD is important for comparability purposes, because external debt is not always quoted in a single currency. For example, only a third (33.7 percent) of Australia's gross foreign debt is denominated in AUD over the sample years (1985-2014), while 40.8 percent is a USD denominated debt and 25.5 percent of liabilities is quoted in other currencies (GBP, CHF, JPY, EUR and others). Noteworthy, if the data on currency composition of foreign debt is not available, we use the aggregate measure converted into USD.

${ }^{8}$ In most cases, we obtain data on foreign debt from International Investment Position reports that are compiled according to IMF's Special Data Dissemination Standard. However, to obtain some data points (mainly for early years) we purchase data from International Country Risk Guide and rely on other sources mentioned in Lane and Milesi-Ferretti (2007).
} 
have high interest rate differentials and exhibit high carry trade returns; examples include Australia and New Zealand. Conversely, low interest rate currencies (like Japan and Switzerland) have relatively low solvency ratio values as well as low carry trade returns. To further assess the observed pattern, we plot the average monthly interest rate differential and average excess returns of developed countries against the average foreign debt-to-GDP ratio over the full sample period (Figure 1). ${ }^{9}$ Both graphs expose differences between low and high interest rate currencies, commonly referred to as funding and investment currencies.

Insert Table 1 here

Insert Figure 1 here

In addition, to test the robustness of the findings, we consider another measure of the economy's ability to finance its official, commercial, and trade debt obligations. Specifically, we rely on the current account-to-exports of goods and services measure (CAXGS) obtained from the International Country Risk Guide published by the PRS Group. This measure is calculated by dividing the current account of the balance of payments for the year in question

${ }^{9}$ Note that in Figure 1 we report historical averages for forward discounts, excess returns, and solvency measure, thus the figure does not necessarily reflect some of the recent tendencies in foreign borrowing. Note also that in both Table 1 and Figure 1 the numerator of solvency measure does not include external bank debt. This significantly reduced solvency measure for countries, like Switzerland and UK, where banking industry has a strong international focus. This adjustment seems plausible, as relatively high level of foreign debt of these counties is due to the size and foreign exposure of their banking sectors and does not reflect solvency risk, which is also indicated by alternative solvency measures. Nevertheless, we check that main findings of this paper hold for solvency measure with and without external bank debt. 
by the estimated aggregate of total exports of goods and services for that year. Both quantities are converted into a U.S. dollar amount beforehand. Results for our alternative measure are reported in the robustness section. Finally, we also consider a composite financial risk measure of the PRS Group, as an alternative solvency measure. ${ }^{10}$ The main results of the paper remain unchanged.

\subsection{Carry trade portfolios and portfolios sorted on solvency ratio}

In order to empirically test the prediction of the model of heterogeneity in carry trade returns exposure to a common risk factor we construct currency portfolios. In particular, to form carry trade portfolios, following Ready, Roussanov and Ward (2015), we sort all of the currencies in our sample into six portfolios (four portfolios for the subsample of developed countries) on the lagged forward discount. Similarly, in order to construct portfolios sorted on a solvency measure we use the foreign debt-to-GDP ratio as in (1).

To ascertain that the portfolio construction process results in empirically implementable trading strategies we operate only with solvency measure data that is available at the time of portfolio construction. Thus, our approach differs from the conventional sorting on one-month lagged forward discount as in Lustig, Roussanov, and Verdelhan (2011) and Menkhoff, Sarno, Schmeling, and Schrimpf (2012). Specifically, due to the availability of macroeconomic data, we adopt an annual portfolio formation period, that is, we rebalance currency portfolios at the end of January of year $t$ based on solvency ratios available for year $t-1$. Similarly, to put carry trade sorts on a par with solvency ratio portfolios, we sort currencies on a one-month forward discount at an annual frequency, rebalancing portfolios at the end of January of each year based

${ }^{10}$ See the supplementary Internet Appendix for the estimation results with PRS group composite financial risk measure. 
on a one-month forward discount at the end of December in year $t-1$. Thus, in both cases, portfolios are rebalanced annually, but average returns are calculated on a monthly basis. Table 1 presents summary statistics for average excess returns of portfolios sorted on forward discounts (Panel A) and solvency measures (Panel B) as well as for components of excess returns, namely, average forward discounts and average change in spot exchange rate.

Insert Table 2 here

Performing sorts on the forward discount results in six equally weighted portfolios where the top (low) sextile comprises currencies with the highest (lowest) forward discounts (interest rate differential) relative to the U.S. dollar. The spread in average excess returns between extreme portfolios in the full sample is similar to that obtained using a traditional sorting procedure with monthly rebalancing as in Menkhoff, Sarno, Schmeling, and Schrimpf (2012). The sample results arising exhibit a monotonic increase in average excess returns across portfolios, a smaller spread in developed sample relative to the full sample results and magnitudes that are similar to the conventional monthly sorts in Lustig, Roussanov, and Verdelhan (2011). In both subsamples the average profitability of the carry trade strategy originates mainly from the average forward discounts across portfolios.

The results of sorting on the solvency measure are reported in Panel B of Table 2. The high portfolio (portfolio 6) captures currencies with the largest values for the economy's solvency measure, while the low portfolio consists of currencies with the smallest values for the foreign debt-to-GDP ratio. The results indicate that the average excess return of portfolios monotonically increases when moving from a low to a high portfolio, in other words, from solvent to insolvent countries. The spread in average excess returns between extreme portfolios is around $2 \%$ per annum in the full sample, which is smaller than the one for carry trade 
portfolios. ${ }^{11}$ However, the magnitudes of spread in average excess returns between the forward discount and solvency measure sorts are more aligned in the sample of developed counties, being $5.09 \%$ and $3.37 \%$ per annum, respectively.

Importantly, and consistent with the outcome predicted, the average forward discount of portfolios also monotonically increases in the values of solvency measure. Specifically, the most solvent countries report low average forward discounts, indicating that those are the countries with the lowest interest rate differentials from the perspective of the U.S. investor. Conversely, the most indebted countries are associated with the highest forward discounts. Similar patterns are evident in the sample of developed countries. The spreads in the average forward discounts between extreme portfolios are close in magnitudes to those from the sort based on forward discount, regardless of the subsample.

\subsection{IMS risk factor and other currency-based risk factors}

Arbitrage pricing theory (APT) (see Ross, 1976) implies that the expected return of assets is approximately linearly related to the factor loadings, in that risk factors capture the common variation in asset returns. The general version of APT, however, is silent on the factors to be used. Lustig, Roussanov, and Verdelhan (2011) show that forward discount sorted portfolios exhibit a strong factor structure, specifically, the large proportion of the average carry trade returns in the cross-section can be explained by two risk factors.

Relying on a similar empirically motivated approach, we strive to pin down heterogeneity in pricing kernels' exposure to a common source of risk, which we previously referred to as a solvency risk. In order to form a candidate risk factor we estimate the difference between the

\footnotetext{
${ }^{11}$ Note that we operate with a large dataset in order to maintain the most complete currency universe possible. Sorting in a smaller set of currencies results in a larger high-minus-low spread, thus a smaller gap between spreads in forward discount and solvency sorted portfolios.
} 
return on the sixth (fourth for developed countries) and the first portfolios sorted on the solvency measure. This factor can be thought of as the U.S. investor's return on a zero-cost strategy that takes long position in the currencies of the countries that are the most indebted and goes short in the currencies of the most solvent countries. We refer to such a strategy as IMS (Indebted-Minus-Solvent). The IMS factor is essentially the implementable trading strategy. In a further estimation, the no arbitrage condition is satisfied, so the price of risk of the IMS factor is equivalent to its average excess return.

The results of principal component analysis indicate that the cross-section of carry trade returns can be explained by two principal component factors: the first is the level factor with similar loadings across portfolios, and the second is the slope factor with a monotonic increase in factor loadings. IMS risk factor is most closely related to the latter principal component (the slope factor) with a correlation coefficient of .71. This is important because the second principal component captures most of the cross-sectional information in the space of portfolio returns. ${ }^{12}$ A further analysis considers both a single IMS factor model and a two factor model with IMS and the level factor depicted by average currency excess returns against the U.S. dollar $\left(D O L_{F X}\right)$.

Additionally, we compare the performance of the IMS factor in explaining cross sectional heterogeneity in the average excess returns of portfolios sorted on the forward discount against other currency-specific risk factors. Specifically, along with the $D O L_{F X}$ risk factor we consider the $H M L_{F X}$ risk factor of Lustig, Roussanov, and Verdelhan (2011) constructed directly from the sorted portfolios as high-minus-low carry trade portfolio returns. Moreover, we construct a global volatility risk factor $V O L_{F X}$ as introduced by Menkhoff, Sarno, Schmeling, and

${ }^{12}$ See Lustig, Roussanov, and Verdelhan (2011) for principal component analysis on currency portfolios and the importance of the second principal component. 
Schrimpf (2012) as an intra-month realized standard deviation of the daily log changes of the spot exchange rates.

\section{Empirical Strategy}

First, since the risk factor in this paper is a portfolio of traded assets, we apply the standard time-series tests. To be precise, we run time-series regressions (5) of each carry trade portfolio's excess return as well as high-minus-low portfolio on a candidate risk factor(s). Further, we check if beta loadings are statistically significant and if alphas both individually and jointly are equal to zero.

$$
r_{i t}=\alpha_{i}+\beta_{i} f_{t}^{\prime}+\varepsilon_{t}
$$

where $r_{i t}$ excess return on portfolio $i$ at time $t, \alpha$ is an intercept, $f^{\prime}$ is the vector of candidate risk factors, and $\varepsilon$ is the residual. To assess significance we rely on Newey and West (1987) HAC standard errors with optimal lags based on Andrews (1991). A J-test $\left(\alpha^{\prime} V_{\alpha}^{-1} \alpha\right)$ is used to test if intercepts are jointly equal to zero.

Next, we turn to the cross-sectional asset pricing, where the empirical approach is based on the argument that there is a stochastic discount factor (henceforth, SDF) that prices all the assets, as in Cochrane (2005). To estimate the market price of risk and the portfolio's betas we rely on two widely used procedures: first, the Generalized Method of Moments (henceforth, GMM) as in Hansen (1982) with linear SDF and, second, Fama and MacBeth (1973) procedure (henceforth, FMB).

In order to rationalize returns to the carry trade strategy one can assume that a currency risk premium defined by a residual $\left(\varepsilon_{t}\right)$ exists: 
$i_{t}^{*}-i_{t}=s_{t+1}-s_{t}+\varepsilon_{t}$

Backing out the risk premium from equation (6), one can show that the risk premium should offset the difference between the actual and expected exchange rate. Revolving around the classic pricing kernel equation, the risk-based explanation implies the absence of arbitrage opportunities and a zero price for such a risk-adjusted excess return. In particular, an excess return to a carry trade strategy must satisfy the Euler equation $\left(E_{t}\left(M_{t+1} r_{t+1}^{i}\right)=0\right)$. Applying the law of iterated expectations, we derive the unconditional version of it with a suppressed expectation time subscript:

$$
E\left(M_{t} r_{t}^{i}\right)=0
$$

where $E$ is an unconditional mathematical expectation; $\alpha=1+b^{\prime} E(f)$, so $M_{t}$ is a linear SDF that takes the form of $M_{t}=1-b^{\prime}\left(f_{t}-\mu\right)$ with $b$ is a vector of factor loading, $f_{t}$ is a vector of factors and $\mu=E(f)$ stands for factor means. In this manner, we force the mean of the SDF to be equal to 1 and the GMM-estimation then performs a cross-sectional regression of mean excess returns on their covariances with the factors. Thus, GMM tests the theoretical prediction that excess returns should be proportional to the covariances between returns and factors, so that:

$$
E\left(r_{t+1}^{i}\right)=\operatorname{cov}\left(r_{t}^{i}, \tilde{f}_{t}^{\prime}\right) \Sigma_{f}^{-1} \Sigma_{f} b
$$

where $\tilde{f}_{t} \equiv f_{t}-E(f)$. Alternatively, in a traditional beta pricing model form with factor risk prices $\lambda$ and factor loadings $\beta$ of portfolio $i$, equation (7) takes the form of $E\left(r_{t}^{i}\right)=\lambda^{\prime} \beta_{i}$ with 
$\lambda=\Sigma_{f} b$ representing the prices of risk, where $\Sigma_{f}=E\left(f_{t}-E(f)\right)\left(f_{t}-E(f)\right)^{\prime}$ is the covariance matrix of the risk factor and $b$ is the coefficient estimates of returns regressed on a factor. We use the GMM procedure (Hansen, 1982) with the following moment conditions as in (9) from (7) for $n \times 1$ vector of excess returns along with $\mu=E\left(f_{t}\right)$ restrictions to empirically estimate the prices of risk and the factor loadings.

$$
E\left(\left[1-b^{\prime}\left(f_{t}-\mu\right) r_{t}^{i}\right)=0\right.
$$

The GMM estimator of $b$ then takes the following form:

$$
\hat{b}=\left(d_{T}^{\prime} W_{T} d_{T}\right)^{-1} d_{T}^{\prime} W_{T} \bar{r}
$$

where $d_{T}$ is a covariance matrix, $W_{T}$ is the weighting matrix.

Throughout the estimations we operate with overidentified GMM systems with a larger number of assets (moment conditions) than number of parameters. In such overidentified systems, it is generally impossible to set all the moments to zero simultaneously, thus we try to set a linear combination of these moments to be as close to zero as possible. In the first step of the procedure to minimize the objective function we use a pre-defined weighting matrix set to be identical matrix $\left(W_{T}=I_{n}\right)$ as a covariance of the moment conditions. This works alongside the starting values, the prices of risk, and the pricing errors computed using an FMB regression. In the second step, we iterate values obtained from the first stage to obtain the optimal weighting matrix and an asymptotically efficient estimate of $\hat{b}$. The price of risk is calculated as $\hat{\lambda}=\hat{\Sigma}_{f} \hat{b}$. We also report Newey-West based standard errors, cross-sectional $R^{2}$, and a J-test of pricing errors $\left(\alpha^{\prime} V_{\alpha}^{-1} \alpha\right)$. In the following table we report estimates of the iterated GMM procedure. 
Furthermore, we report the results of the traditional FMB procedure, which is similar to the first stage of the GMM. In particular, to obtain estimates of interest we run a cross-sectional regression of average portfolio excess returns on the previously estimated first step time-series betas. Note, that we do not include the constant in the second stage in the following models with dollar risk factor as it captures a common variation in returns similar to the constant. For FMB we report both Shanken (1992) and Newey-West standard errors.

\section{Empirical Evidence}

This section presents our main empirical results regarding the predictions of heterogeneity in carry trade returns exposure to a common solvency risk factor. First we estimate exposure of the portfolios' covariances to common risk by estimating the model with only one linear risk factor (IMS). Subsequently, we assess the performance of the model enhanced with dollar risk factor $\left(D O L_{F X}\right)$. Finally, the performance of the model is compared to alternative currencyspecific risk factor models.

5.1 Explaining the carry trade with the solvency factor

Table 3 reports the results of benchmark asset pricing tests described in the previous section, as we test the ability of the candidate pricing kernel, linearly defined by the single IMS risk factor, to price the six (four for developed countries) carry trade portfolios sorted on forward discount.

Insert Table 3 here

Panel A of Table 3 presents results of time series regressions of each portfolio's log carry trade excess returns $r^{i}$ on an intercept and solvency risk factor alone. We report estimates for 
the constant $\alpha^{i}$ and the slope coefficient $\beta_{I M S}$ as well as adjusted R-squares and joint test for alphas. The alphas are presented in percentage points. The individual portfolio's alphas are not statistically different from zero, albeit high carry trade portfolios in both samples (all and developed countries) record alphas that are significant at $1 \%$ and 5\%, respectively. The joint test for alphas yields mixed results for the two subsamples, as the null that the alphas are jointly zero is rejected in the full sample, while confirmed in the sample of developed countries at $5 \%$ level (p-value of 0.07).

The IMS factor loadings of each individual portfolio are reported in the second column. Betas for the IMS risk factor increase monotonically from -0.16 for low portfolio (low interest rate currencies) to 0.34 for high portfolio ones, while being significantly different from zero for the extreme portfolios. Essentially, a similar monotonic pattern in solvency risk exposure occurs in the sample of developed countries (the right-hand side of the table). Additionally, the IMS risk factor is capable of pricing the high-minus-low carry trade strategy (last row of Panel A).

Panel B of Table 3 reports results of standard cross-sectional asset pricing tests. GMM refers to the iterated SDF-GMM estimation and FMB stands for the Fama-MacBeth approach. Importantly, the IMS risk factor exhibits a positive and significant price of risk $\left(\lambda_{I M S}\right)$ in most of the tests. The risk price is 17.19 for the full sample and 6.19 for the developed country sample, while both values are more than two standard errors away from zero (with GMM errors equal to 353 and 284 b.p., respectively), and are thus statistically significant. Overall, the results broadly indicate that the IMS factor is priced and alone can partially explain the crosssectional variation in expected returns with the $R^{2}$ of $43 \%$ (in the full sample). ${ }^{13}$

\footnotetext{
${ }^{13}$ Additionally, since the factor is traded return, we check that the IMS risk factor is able to price itself and that the risk price of the IMS factor is roughly equal to the mean return of the IMS trading strategy. We find that this is indeed the case, thus no-arbitrage condition is satisfied. The relevant results are reported in Appendix.
} 
Next, we consider the model with two risk factors, namely the dollar risk factor $\left(D O L_{F X}\right)$ and the solvency risk factor (IMS). The dollar risk factor is highly correlated with the first principal component (0.98), captures common variation across portfolios and naturally can be interpreted as a currency-specific market level risk factor. Table 4 shows the estimates of factors loadings and cross sectional asset pricing results for the two factor model.

\section{Insert Table 4 here}

The upper panel of Table 4 presents time series regression statistics for the two factor model with carry trade portfolios as the test assets. The introduction of the dollar risk factor (DOL) results in smaller pricing errors, greater explanatory power, and an overall better fit for the model. Factor loadings on the DOL factor (the level factor) are all close to one in value, and statistically significant. Importantly, the IMS factor betas are essentially unchanged from those in a single factor model. Again, we observe a striking monotone increase in IMS factor betas when moving from portfolio 1 (low interest rate currencies) to portfolio 6 (high interest rate currencies), which precisely produces a large spread in portfolio's mean returns (see Table 2). The IMS betas for the first three portfolios are negative and uniformly statistically significant. The betas for the last two portfolios are positive. The individual pricing errors are low for all six regressions, while (mostly) being not statistically different from zero. Similar results are observed in the sample of developed countries (the right-hand side of the table); furthermore, alphas are not statistically significant either individually or jointly.

Next, we show that observed betas are driven by covariances between the log spot exchange rate change and the solvency risk. Essentially, we run time series regression of logarithmic exchange rate change for each portfolio on the DOL and IMS factors and find beta coefficients on the IMS factor are identical in magnitude, but opposite in sign to those in Table 4. As 
expected, conditional covariance between carry returns and solvency risk factor $\left(\operatorname{cov}_{t}\left(r_{t+1}^{i}, I M S_{t+1}\right)\right)$ equates to negative covariance between the spot rate change and solvency risk $\left(\operatorname{cov}_{t}\left(\Delta s_{t+1}^{i}, I M S_{t+1}\right)\right) .{ }^{14}$ These findings indicate that low carry trade currencies (often referred as funding currencies) provide a hedge against solvency risk (in that they commove negatively with the IMS risk factor) as they appreciate during episodes of low solvency risk. Conversely, high carry trade currencies (investment currencies) payoff badly (depreciate) when the IMS factor exhibits low returns, expose investors to more risk, and thus demand a higher risk premium.

The bottom panel of Table 4 shows the results of cross-sectional asset pricing tests for the two factor model. We perform tests on carry trade excess returns in levels, not on logarithmic returns, and do not include the constant in the second stage of FMB procedure $\left(\lambda_{0}=0\right)$ to avoid redundancy with the dollar risk factor. The price of risk of the IMS factor is once again large and highly statistically significant in both samples, being more than two standard errors away from zero. The dollar risk factor is, however, on the borderline of statistical significance. Inclusion of the DOL factor results in low values for the square root of mean-squared errors (RMSE) for both iterated GMM and FMB procedures. At the same time, regardless of the subsample, the cross-sectional $R^{2}$ values are as high as $96 \%$.

Overall, the results indicate that the model with DOL and IMS factors provides a good crosssectional fit. The solvency-sorted and forward-discount-sorted portfolios are exposed to a risk of a common origin that spurs the heterogeneity in average excess returns. The results suggest that the IMS factor is an empirically powerful risk factor and explains the cross sectional variation in carry trade returns.

\footnotetext{
${ }^{14} \mathrm{We}$ report results of these regressions in the Appendix.
} 
The question, however, is whether the IMS risk factor conveys any additional pricing information that is not captured by the existing currency-specific risk factors. This is important because the previously proposed $H M L_{F X}$ and $V O L_{F X}$ factors are found to have a large crosssectional pricing capacity and both, as well as IMS, are closely related to the second principal component. Next we address this concern.

\subsection{Horse races between currency-specific factors}

Thus far results indicate that the IMS factor is a powerful pricing factor and, being closely related to the second principal component, provides a high cross-sectional fit. Next, we challenge the pricing competency of the proposed factor against well-established currency based risk factors, namely, the high-minus-low carry trade returns $\left(H M L_{F X}\right)$ and the global FX volatility innovations risk factor $\left(V O L_{F X}\right)$. First, we test factors by concurrently including them in the SDF together with the dollar risk factor. The result is two models where the SDF is linearly defined as in Lustig et al. (2011) (Panel A of Table 5) or in Menkhoff et al. (2012) (Panel B of Table 5), but enhanced with the IMS factor. Second, we test two modifications of the model comprising the $D O L$, the $H M L_{F X}$ and the $I M S$ risk factors in which we sequentially orthogonalize the latter two factors against each other.

\section{Insert Table 5 here}

Importantly, the results of the iterated GMM procedure in Panels A and B indicate that the solvency risk factor (IMS) does not become attenuated when included in the model with the $H M L_{F X}$ and $V O L_{F X}$, respectively. In both panels all of the factors, including the IMS factor, are significantly priced with lambdas that are more than two standard errors away from zero, albeit the $H M L_{F X}$ dominates the solvency factor in significance. Notably, jointly specified 
SDFs improve on the cross-sectional explanatory power $\left(R^{2}\right.$ of $97 \%$ and $\left.92 \%\right)$ and the meansquared errors (RMSE of 0.84 and 1.49) relative to any of the individual specifications.

Panels C and D report iterated GMM estimates for the SDFs enhanced with either the IMS or the $H M L_{F X}$ orthogonal components. Specifically, the IMS factor is orthogonalized with respect to the $H M L_{F X}$ in Panel C and, conversely, the $H M L_{F X}$ is orthogonalized with respect to the IMS in Panel D. As a result, in that test design we are able deconfound the effects of the slope factors and avert the statistical inference problems. First, the orthogonalized component of the solvency risk factor is priced (the GMM t-stat. of 3.70) in the joint SDF specification (Panel C). This indicates that the IMS factor has a supplementary pricing capacity over the $H M L_{F X}$ factor. The results presented in Panel D confirm that the orthogonalized constituent of the $H M L_{F X}$ lacks pricing power when jointly estimated with the IMS factor, while the latter is still significantly priced with the GMM $t$-statistic being 2.23 .

Armed with the aforementioned evidence, we suggest that the IMS factor is not only significantly priced, but also captures additional information in the cross-section of carry trade returns that is unexplained by other currency-specific risk factors, namely the carry risk factor and the FX volatility. It is notable that, the $H M L_{F X}$ risk is clearly pervasive in the cross-section of currency carry trade returns and dominates in significance. However, the $H M L_{F X}$ is constructed directly from the forward-discount-sorted returns; and thus reflects the monotonic patterns of carry returns and is strongly related to the second principal component. Diversely, the IMS has to be estimated and, potentially, embodies measurement error problems, as solvency ratio is calculated using macroeconomic data. Nevertheless, the IMS factor is a competitive risk factor, seizes additional information ancillary to that commonly explained by prominent risk factors and, furthermore, improves on standard errors and explanatory power. Thus, it seems fair to conclude that the solvency risk is priced in the cross-section of currency carry trade returns. 


\section{Robustness}

This section presents a battery of supplementary empirical findings on the robustness of the solvency risk-based explanation of carry trade returns under various modifications.

\subsection{Asset pricing: Splitting Samples}

First, we perform a conventional sample split test. Specifically, we split the full sample in halves so the left-hand panel of Table 6 covers the period from January 1985 to December 1999 and the right-hand panel presents results for the second half of the period (January 1999 to December 2014).

\section{Insert Table 6 here}

The outcomes of the half-splitting procedure applied to the sample validate a previous finding that solvency risk is priced in the cross-section, and the process also ensures that results are not unduly affected by outliers and are not prone to a mechanical returns-factor relationship. Regardless of the subsample, the beta loadings on the IMS risk factor increase when moving from a low to a high carry portfolio, albeit not as monotonically as corresponding estimates in Table 4. In addition, both individual and joint pricing errors are mainly low and not significant, while cross-sectional fit is high. Risk premia differ considerably in magnitudes and significance between the two subsamples, perhaps due to small sample period. Nevertheless, at least for the latter sample we find that the implied price of solvency risk estimates remains significant. Overall, the results are reassuring. 
To further assess robustness, we consider an alternative solvency measure: current accountto-export of goods and services (CAXGS), which is the ratio of the balance of the current account of the balance of payments for the year in question to the estimated aggregate of total exports of goods and services for that. The portfolios sorting and empirical estimation procedures are similar to that shown in Table 4, with only exception that SDF is now linearly defined by the dollar risk factor (DOL) and the alternatively specified indebted-minus-solvent risk factor (further $I M S_{\mathrm{CXGS}}$ ). Not surprisingly, the $I M S_{\mathrm{CXGS}}$ is positively, but not perfectly correlated, with the IMS with a correlation coefficient of .58 for the full sample.

\section{Insert Table 7 here}

Essentially, the results of the analysis based on the alternatively specified solvency measure (Table 7) are very similar to those reported in Table 4 . The dispersion in the intercepts is now a little larger compared to the IMS results, consistent with the larger dispersion in the $I M S_{\mathrm{CXGS}}$ beta loadings. Importantly, we still observe an increasing monotonic pattern in factor loadings $\left(\beta_{C X G S}^{I M S}\right)$ from the first to the last portfolio. Moreover, the solvency price of risk estimates, obtained by the abovementioned cross-sectional asset pricing tests, is positive and significant, with the magnitudes of the premia, in either sample, being like its counterparts in Table 4. Moreover, we find a cross-sectional $R^{2}$ of $86 \%$ and a square root of mean-squared errors of 1.92 for the full sample, indicating weaker explanatory capacity relative to IMS enhanced model, but still a high level of cross-sectional fit. Overall, the findings again suggest that investors require a risk premium on currencies that co-vary more with the solvency risk factor, as they are riskier and thus deliver higher excess returns. Hence, the solvency risk-based explanation of carry trade returns is robust against alternative measures of solvency. 


\subsection{Various portfolio formation dates}

Thus far, in our empirical analysis we formed portfolios based on advance macroeconomic estimates available at the end of January. Although, such estimates are usually reliable and accurate projections of the actual values, they are often further revised and corrected. In order to ensure that constructed portfolios reflect an implementable trading strategy based on accurate macroeconomic estimates, we repeat the empirical analysis with portfolios sorted on the solvency measure data available on various dates. To do so, we run asset pricing tests with portfolios sorted on both the previous month's forward discount and previous year's macroeconomic data available to investors at the end of March (second estimates), June (third estimates) and December (final updates).

\section{Insert Table 8 here}

The results presented in Table 8 are analogous to those in Table 4, as we observe a similar monotonic increasing pattern in factor betas and significant risk prices for the information sets available on the aforementioned dates. Thus, it seems reasonable to conclude that the IMS risk factor is an empirically powerful risk factor and robust in the face of various formation dates. In this regard, the finding of the time-varying solvency risk premia are the source of the carry trade returns is further reinforced by the evidence from the solvency trading strategies' temporal implementable efficacy.

\subsection{Other robustness tests}

We also perform a number of supplementary robustness checks of various types. First, we ensure that main results of the paper do not originate from a small number of funding/investment currencies and are not sample-specific, but rather comprehensively robust 
in the cross-section of carry trade returns. For this purpose, we exclude currencies with the most of extreme portfolio hits on both sides from the dataset and re-estimate the model from Section 5.1. Additionally, in the interest of conscience we show that significant risk price of solvency factor persist when intercept is included in the second stage of FMB estimations. Second, we examine if the results of the paper are robust internationally. Daniel, Hodrick, and Lu (2017) argue that carry trade performance and risk characteristics depend on the choice of funding (base) currency. In order to demonstrate that our findings are robust in the face of an alternative funding currency, we take the Japanese investor point of view, consider the Japanese Yen as a base currency, and repeat the empirical analysis. Third, we consider another alternative proxy for solvency risk - the composite financial risk measure - that essentially is the aggregate estimate of country's financial competency indicators, such as, alternatively specified external debt service capacity, exchange rate stability, and the country's international liquidity, converted into scores.

Next, to guard against the known shortcomings of portfolio construction, such as the possibility of security-idiosyncratic information loss (Litzenberger and Ramaswamy, 1979), we follow the prescriptions of Lo and MacKinlay (1990) and perform currency-level asset pricing tests. ${ }^{15}$ Specifically, we test the pricing ability of the solvency risk factor using the sample of individual currencies as test assets. Further, we address Lewellen, Nagel and Shanken's (2010) skepticism of cross-sectional tests in low dimensional return space by expanding the set of test portfolios beyond carry trade portfolios. For this purpose, we employ a large set of currency portfolios (30 in total) and perform cross-sectional tests with and without solvency and forward discount sorted portfolios.

\footnotetext{
${ }^{15}$ For more evidence on importance of security-level tests see, e.g. Brennan, Chordia, and Subrahmanyam (1998), Avramov and Chordia (2006) and the references therein.
} 
Although ultimately the results of a few tests deviate from the central findings of the paper, principally, the robustness checks confirm that the solvency risk is priced in these cross sections of carry trade returns. In most of the tests the solvency risk factor posts a similar asset pricing estimates to the counterpart's values in the benchmark specifications of the previous sections. In the interest of conciseness, we provide the discussion on some of the aforementioned robustness procedures and document the corresponding empirical results in the supplementary Internet Appendix. ${ }^{16}$

\section{Conclusions}

Currency carry trade profitability emerges from exploitable failures of foreign exchange parity relations, that is, currencies traded on a forward premium are apt to appreciation, contrarily to the UIP predicted depreciation. There is abundant evidence suggesting the existence of common determinants of inter-temporal variations in carry trade returns, which lends support to a rationalization of strategy returns as a compensation for common risk. This implies persistent differences in risk exposures across countries is the source of carry trade profitability. This paper sheds light on a possible origin of such heterogeneity and offers a new risk-based explanation for currency risk premia.

This study builds on the classic APT approach in explaining the cross-section of carry trade returns and identifies persistent heterogeneity in loadings on a common component across countries' pricing kernels. We argue that currency carry trade returns can be rationalized by the time-varying risk premia that originate from the sovereign solvency risk. Specifically, we

\footnotetext{
${ }^{16}$ In addition, in unreported results we confirm results of our the empirical analysis by using various data samples identical to several prominent carry trade literature studies, introducing transaction costs to the data, performing additional sample partitioning and controlling for existing stock and bond market risk factors.
} 
suggest that solvency risk maintains the substantial power to explain the cross-section of carry trade returns. The solvency sorted and forward discount sorted portfolios are exposed to a risk of a common origin that spur on the heterogeneity in average excess returns. In line with that, heterogeneous risk exposures of currencies reveal that low carry trade currencies serve as hedge against solvency risk, while high carry trade currencies depreciate, exposing investors to more risk and requiring a higher risk premium. Hinging on classic asset pricing procedures we introduce a new, solvency-based, risk factor and show that its covariance with returns accounts for a large part of cross-sectional variation across portfolios. The factor is empirically powerful and withstands a battery of different robustness checks.

The cumulative evidence points to the solvency risk factor as an effective tool for pricing the cross-section of carry returns. Accordingly, the overall results offer a new interpretation of currency risk premia, and, inter alia, an unambiguous risk-based perspective on the forward premium puzzle.

\section{References}

Andrews, D. 1991. Heteroskedasticity and autocorrelation consistent covariance matrix estimation. Econometrica 59:817-858.

Ang A., and F. A. Longstaff. 2013. Systemic sovereign credit risk: Lessons from the U.S. and Europe. Journal of Monetary Economics 60:493-510.

Avramov, D., and T. Chordia. 2006. Asset pricing models and financial market anomalies. Review of Financial Studies 19:1001-1040.

Bardhan, P.K. 1967. Optimum foreign borrowing. Essays on the Theory of Optimal Economic Growth, ed. by K. Shell, MIT Press 117-128.

Bhandari, J. S., N. Haque, and S. J. Turnovsky. 1990. Growth, external debt, and sovereign risk in a small open economy. IMF Staff Papers 37(2):388-417.

Bilson, J. F. 1981. The 'speculative efficiency' hypothesis. Journal of Business 54:435-451. 
Brennan, M. J., Chordia, T., and A. Subrahmanyam. 1998. Alternative factor specifications, security characteristics, and the cross-section of expected stock returns. Journal of Financial Economics 49:345-37.

Brunnermeier, M., S. Nagel, and L. H. Pedersen. 2009. Carry trade and currency crashes. NBER Macroeconomics Annual 23:313-347.

Burnside C., B. Han, D. Hirshleifer, and T. Y. Wang. 2011. Investor overconfidence and the forward premium puzzle. Review of Economic Studies 78 (2):523-558.

Burnside C., M. S. Eichenbaum, I. Kleshchelski, and S. Rebelo. 2011. Do peso problems explain the returns to the carry trade? Review of Financial Studies 24:853-891.

Burnside C., M. S. Eichenbaum, and S. Rebelo. 2011. Carry trade and momentum in currency markets. Annual Review of Financial Economics 3:511-535.

Cochrane, J. H. 2005. Asset Pricing. (Princeton University Press, NJ).

Cohen D., and J. Sachs. 1986. Growth and external debt under risk of debt repudiation. European Economic Review 30:437-472.

Coudert, V., and V. Mignon. 2013. The "forward premium puzzle" and the sovereign default risk. Journal of International Money and Finance 32:491-511.

Daniel, K., R. J. Hodrick, and Z. Lu. 2017. The carry trade: Risks and Drawdowns. Critical Finance Review, forthcoming.

Della Corte, P., L. Sarno, M. Schmeling, and C. Wagner. 2016. Exchange rates and sovereign risk. Working paper.

Della Corte, P., S.J. Riddiough, and L. Sarno. 2016. Currency premia and global imbalances, Review of Financial Studies 29:2161-2193.

Diamond, P. A. 1965. National debt in a neoclassical growth model. American Economic Review 55(5):1126-1150.

Eaton, J., and S. J. Turnovsky. 1983. Covered interest parity, uncovered interest parity and exchange rate dynamics. Economic Journal 93:555-575.

Engel, C. 1996. The forward discount anomaly and the risk premium: a survey of recent evidence. Journal of Empirical Finance 3:123-192.

Escudé G. J. 2013. A DSGE model for a SOE with systematic interest and foreign exchange policies in which policymakers exploit the risk premium for stabilization purposes. $B C R A$ working paper no. 201361.

Evans, M. D. 1996. Peso problems: Their theoretical and empirical implications. Handbook of Statistics 14:613-646. 
Evans, M. D. and R. K. Lyons. 2002. Order flow and exchange rate dynamics. Journal of Political Economy 110:170-180.

Fama, E. F. 1984. Forward and spot exchange rates. Journal of Monetary Economics 14:319338.

Fama, E. F., and J. D. MacBeth. 1973. Risk, return, and equilibrium: Empirical tests. Journal of Political Economy 81:607-636.

Fama, E. F., and K. French. 1993. Common risk factors in the returns on stocks and bonds. Journal of Financial Economics 33:3-56.

Froot, K., and R. Thaler. 1990. Anomalies: foreign exchange. Journal of Economic Perspectives 4:179-192.

Gabaix, X., and M. Maggiori. 2015. International liquidity and exchange rate dynamics. Quarterly Journal of Economics 130:1369-1420.

Gomes, J., and L. Schmid. 2012. Equilibrium credit spreads and the macroeconomy. Working Paper, Fuqua School of Business.

Hansen, L. P. 1982. Large sample properties of generalized method of moments estimators. Econometrica 50:1029-1054.

Hansen, L. P., and R. J. Hodrick. 1980. Forward exchange rates as optimal predictors of future spot rates: An econometric analysis. Journal of Political Economy 88:829-853.

Hansen, L. P., and R. J. Hodrick. 1983. Risk-averse speculation in the forward foreign exchange market: An econometric analysis of linear models. in Jeffrey A. Frankel, ed. Exchange Rates and International Macroeconomics (University of Chicago Press, Chicago).

Hui C. H., and T. K. Chung. 2011. Crash risk of the Euro in the sovereign debt crisis of 20092010. Journal of Banking and Finance 35:2945-2955.

Huang H., and R. MacDonald. 2014. Currency carry trades position-unwinding risk and sovereign credit premia. EFMA 2015 working paper.

Jurek, J. 2014. Crash-neutral currency carry trades. Journal of Financial Economics 113 (3): $325-347$.

Kaminsky, G. 1993. Is there a peso problem? Evidence from the dollar/pound exchange rate, 1976-1987. American Economic Review 8:450-472.

Karnaukh, N., A. Ranaldo, and P. Söderlind. 2015. Understanding FX liquidity. Review of Financial Studies 11:3073-3108. 
Kharas, H.J. 1983. Constrained optimal foreign borrowing by less developed countries, World Bank working paper series (Washington, DC).

Kharas, H.J., and H. Shishido. 1986. Optimal borrowing and overborrowing: Some simple simulation lessons. World Bank working paper series (Washington, DC).

Krasker, W. S. 1980. The 'peso problem' in testing the efficiency of forward foreign exchange markets. Journal of Monetary Economics 6:269-276.

Lane, P., and G. Milesi-Ferretti. 2007. The external wealth of nations mark II: Revised and extended estimates of foreign assets and liabilities, 1970-2004. Journal of International Economics 73:223-250.

Lane, P., and J. Shambaugh. 2010. Financial exchange rates and international currency exposure. American Economic Review 100:223-250.

Lettau, M., M. Maggiori, and M. Weber. 2014. Conditional risk premia in currency markets and other asset classes. Journal of Financial Economics 114:197-225.

Lewellen, J., S. Nagel, and J. Shanken. 2013. A skeptical appraisal of asset pricing tests. Journal of Financial Economics 96:175-194.

Litzenberger, R., and K. Ramaswamy. 1979. The effect of personal taxes and dividends on capital asset prices: Theory and empirical Evidence. Journal of Financial Economics 7:163-195.

Lo, A. W., and A. C. MacKinlay. 1990. Data-snooping biases in tests of financial asset pricing models. Review of Financial Studies 3:431-468.

Longstaff, F. A., J. Pan, L. H. Pedersen, and K. J. Singleton. 2011. How sovereign is sovereign credit risk? American Economic Journal: Macroeconomics 3:75-103.

Lustig, H., N. Roussanov, and A. Verdelhan. 2011. Common risk factors in currency markets. Review of Financial Studies 24:3731-3777.

Lustig, H., and A. Verdelhan. 2007. The cross section of foreign currency risk premia and consumption growth risk. American Economic Review 97:89-117.

Lyons, R. K. 2001. The microstructure approach to exchange rates. December 2000. MIT Press.

Mancini, L., A. Ranaldo, and J. Wrampelmeyer 2013. Liquidity in the foreign exchange market: Measurement, commonality, and risk premiums. Journal of Finance 68:1805-1841.

Mano, R. 2013. Exchange rates upon sovereign default. Working Paper, International Monetary Fund. 
Menkhoff, L., L. Sarno, M. Schmeling, and A. Schrimpf. 2012. Carry trades and global foreign exchange volatility. Journal of Finance 67:681-718.

Newey, W., and K. West. 1987. A simple, positive semi-definite, heteroskedasticity and autocorrelation consistent covariance matrix. Econometrica 55: 703-708.

Obstfeld, M. 1982. Aggregate spending and the terms of trade: Is there a Laursen-Metzler effect? Quarterly Journal of Economics 97:251-70.

Otani, I., and D. Villanueva. 1988. Theoretical aspects of growth in developing countries: External debt dynamics and the role of human capital. IMF Working Papers WP/88/5.

Ranaldo, A., and P. Söderlind. 2010. Safe haven currencies. Review of Finance 10:385-407.

Ready, R., N. Roussanov, and C. Ward. 2016. Commodity trade and the carry trade: A tale of two countries. Journal of Finance, forthcoming.

Reinhart, C. 2002. Default, currency crises, and sovereign credit ratings. World Bank Economic Reviews 16:151-70.

Ross, S. A. 1976. The arbitrage theory of capital asset pricing. Journal of Economic Theory $13: 341-60$.

Schmitt-Grohe, S., and M. Uribe. 2003. Closing small open economy models. Journal of International Economics 61:163-185.

Shanken, J. 1992. On the estimation of beta-pricing models. Review of Financial Studies 5:133. 
Table 1: Developed currencies and solvency measures

\begin{tabular}{lccc}
\hline \hline Currency & Forward discount & Excess Return & Solvency Measure \\
\hline GBP & 0.16 & 0.24 & 16.17 \\
CHF & -0.13 & 0.14 & 7.44 \\
JPY & -0.21 & 0.00 & 16.52 \\
CAD & 0.07 & 0.11 & 14.68 \\
AUD & 0.27 & 0.27 & 62.10 \\
NZD & 0.36 & 0.50 & 76.86 \\
SEK & 0.13 & 0.17 & 39.47 \\
NOK & 0.18 & 0.23 & 6.64 \\
DKK & 0.08 & 0.25 & 22.47 \\
EUR/DEM & -0.02 & 0.35 & 16.39 \\
\hline \hline
\end{tabular}

Note: Table presents descriptive statistics for average monthly forward discounts, average monthly excess returns (without bid-ask spread) and average foreign debt to GDP ratio (solvency measure) for the ten most traded carry trade currencies. Time period spans from 01/1985 to 12/2014. Pre-1999 data on German Mark is merged with post-1999 data on Euro. 
Table 2: Portfolios sorted on forward discount and solvency measure

\begin{tabular}{|c|c|c|c|c|c|c|c|c|c|c|}
\hline Portfolio & 1 & 2 & 3 & 4 & 5 & 6 & 1 & 2 & 3 & 4 \\
\hline \multicolumn{11}{|c|}{ Panel A: Portfolios Sorted on Forward Discounts } \\
\hline & \multicolumn{6}{|c|}{ All Countries } & \multicolumn{4}{|c|}{ Developed countries } \\
\hline & \multicolumn{6}{|c|}{ Spot change: $\Delta s^{i}$} & \multicolumn{4}{|c|}{$\Delta s^{i}$} \\
\hline Mean & -2.34 & -1.74 & -2.05 & -0.51 & 1.07 & 3.07 & -2.37 & -2.47 & 0.07 & -1.28 \\
\hline $\mathrm{SD}$ & 7.79 & 7.07 & 8.16 & 8.08 & 9.24 & 9.68 & 9.89 & 8.78 & 8.73 & 11.25 \\
\hline & \multicolumn{6}{|c|}{ Forward discount: $f^{i}-s^{i}$} & \multicolumn{4}{|c|}{$f^{i}-s^{i}$} \\
\hline Mean & -2.07 & -0.59 & 0.45 & 2.10 & 3.34 & 13.09 & -1.96 & 0.18 & 1.89 & 4.23 \\
\hline \multirow[t]{2}{*}{ SD } & 3.16 & 0.49 & 1.45 & 0.56 & 1.49 & 3.96 & 0.69 & 0.50 & 0.69 & 1.00 \\
\hline & \multicolumn{6}{|c|}{ Excess returns: $r^{i}$} & \multicolumn{4}{|c|}{$r^{i}$} \\
\hline Mean & 0.27 & 1.15 & 2.50 & 2.62 & 2.27 & 10.02 & 0.42 & 2.65 & 1.81 & 5.51 \\
\hline SD & 8.26 & 6.95 & 8.21 & 7.94 & 9.08 & 10.59 & 9.94 & 8.81 & 8.79 & 11.35 \\
\hline SR & 0.03 & 0.17 & 0.30 & 0.33 & 0.25 & 0.95 & 0.04 & 0.30 & 0.21 & 0.49 \\
\hline \multicolumn{11}{|c|}{ Panel B: Portfolios Sorted on Solvency Measure } \\
\hline & \multicolumn{6}{|c|}{ All Countries } & \multicolumn{4}{|c|}{ Developed countries } \\
\hline & \multicolumn{6}{|c|}{ Spot change: $\Delta s^{i}$} & \multicolumn{4}{|c|}{$\Delta s^{i}$} \\
\hline Mean & -1.94 & -0.85 & -0.10 & -0.31 & -0.67 & 1.92 & -2.36 & -0.79 & -0.93 & -1.95 \\
\hline $\mathrm{SD}$ & 9.44 & 7.92 & 6.38 & 6.66 & 8.44 & 10.75 & 10.50 & 8.47 & 8.87 & 10.56 \\
\hline & \multicolumn{6}{|c|}{ Forward discount: $f^{i}-s^{i}$} & \multicolumn{4}{|c|}{$f^{i}-s^{i}$} \\
\hline Mean & 0.25 & 1.82 & 2.89 & 3.23 & 3.64 & 6.23 & -0.77 & 1.25 & 1.58 & 3.01 \\
\hline \multirow[t]{2}{*}{ SD } & 0.80 & 0.73 & 0.84 & 1.63 & 3.05 & 4.07 & 0.68 & 0.69 & 0.95 & 0.70 \\
\hline & \multicolumn{6}{|c|}{ Excess returns: $r^{i}$} & \multicolumn{4}{|c|}{$r^{i}$} \\
\hline Mean & 2.18 & 2.66 & 2.99 & 3.54 & 4.30 & 4.31 & 1.59 & 2.04 & 2.51 & 4.96 \\
\hline SD & 9.43 & 7.95 & 6.45 & 7.03 & 8.87 & 11.36 & 10.54 & 8.52 & 8.98 & 10.66 \\
\hline SR & 0.23 & 0.34 & 0.46 & 0.50 & 0.49 & 0.38 & 0.15 & 0.24 & 0.28 & 0.47 \\
\hline
\end{tabular}

Note: The table reports descriptive statistics (annualized) for portfolios sorted on forward discounts (carry trade) and on solvency measure (foreign debt to GDP) for the full sample (left side) and developed countries (right side). Mean and standard deviation are reported for spot exchange rate changes, forward discounts and excess returns for each portfolio. Returns are monthly and updated on the annual basis based on previous year values of solvency measure and current forward discounts. Returns do not take into account bid-ask spreads. The sample period is January 1985 - December 2014. 
Table 3. Asset Pricing: IMS risk factor

\begin{tabular}{|c|c|c|c|c|c|c|c|c|}
\hline \multicolumn{9}{|c|}{ Panel A. Factor Betas } \\
\hline \multirow[b]{2}{*}{ Portfolio } & \multicolumn{4}{|c|}{ All Countries } & \multicolumn{4}{|c|}{ Developed Countries } \\
\hline & $\alpha$ & $\beta_{I M S}$ & adj. $-R^{2}$ & $\mathrm{~J}$ & $\alpha$ & $\beta_{I M S}$ & $\operatorname{adj} .-R^{2}$ & $\mathrm{~J}$ \\
\hline \multirow[t]{2}{*}{1} & 0.09 & -0.16 & 3.37 & & 0.22 & -0.44 & 16.70 & \\
\hline & $(0.53)$ & $(-2.20)$ & & & $(1.35)$ & $(-6.00)$ & & \\
\hline \multirow[t]{2}{*}{2} & 0.14 & -0.12 & 2.71 & & 0.31 & -0.17 & 3.10 & \\
\hline & $(1.20)$ & $(-1.89)$ & & & $(1.79)$ & $(-2.41)$ & & \\
\hline \multirow[t]{2}{*}{3} & 0.26 & -0.09 & 1.11 & & 0.20 & -0.05 & 0.22 & \\
\hline & $(1.50)$ & $(-1.16)$ & & & $(1.22)$ & $(-0.65)$ & & \\
\hline \multirow[t]{2}{*}{4} & 0.24 & 0.00 & 0.00 & & 0.45 & 0.21 & 3.08 & \\
\hline & $(1.54)$ & $(0.03)$ & & & $(2.27)$ & $(1.87)$ & & \\
\hline \multirow[t]{2}{*}{5} & 0.22 & 0.03 & 0.11 & & & & & \\
\hline & $(1.37)$ & $(0.34)$ & & & & & & \\
\hline \multirow[t]{2}{*}{6} & 0.81 & 0.34 & 10.14 & & & & & \\
\hline & $(3.81)$ & $(2.67)$ & & & & & & \\
\hline J-test & & & & 32.82 & & & & 8.71 \\
\hline (p-value) & & & & 0.00 & & & & 0.07 \\
\hline \multirow[t]{2}{*}{ High-Low } & 0.72 & 0.50 & 22.11 & & 0.23 & 0.66 & 31.73 & \\
\hline & $(3.82)$ & $(5.61)$ & & & $(1.59)$ & $(7.36)$ & & \\
\hline \multicolumn{9}{|c|}{ Panel B. Risk Prices } \\
\hline \multirow[b]{2}{*}{ GMM } & \multicolumn{4}{|c|}{ All Countries } & \multicolumn{4}{|c|}{ Developed Countries } \\
\hline & IMS & $R^{2}$ & RMSE & & IMS & $R^{2}$ & RMSE & \\
\hline \multirow{2}{*}{$\begin{array}{l}\lambda \\
\text { [s.e.] }\end{array}$} & 17.91 & 42.97 & 3.64 & & 6.19 & 12.44 & 3.86 & \\
\hline & [3.53] & & & & [2.84] & & & \\
\hline FMB & IMS & $R^{2}$ & RMSE & & IMS & $R^{2}$ & RMSE & \\
\hline \multirow{2}{*}{$\begin{array}{l}\lambda \\
{[\mathrm{NW}]}\end{array}$} & 19.17 & 43.16 & 3.64 & & 1.13 & 0.66 & 3.62 & \\
\hline & [3.63] & & & & [3.29] & & & \\
\hline [Sh.] & [3.64] & & & & [3.31] & & & \\
\hline
\end{tabular}

Note: The table reports time-series regressions and cross-sectional asset pricing test results for the linear factor model based on a single IMS (indebted-minus-solvent) factor. The IMS factor is based on solvency measure (foreign debt-to-GDP) sorts. Returns are monthly and portfolios are rebalanced on an annual basis. Results for the sample of all countries are presented in the left-hand panel and for developed countries in the right-hand panel. Panel A reports estimates for monthly time series regressions of (log) carry trade excess returns on the intercept and the IMS risk factor for each forward discount sorted portfolio and the high-minus-low carry trade portfolio. These estimates are: the constant ( $\alpha$ ) (in percentage points); the IMS factor loading $\left(\beta_{I M S}\right)$; and the adjusted- $R^{2}$ (in percentage points). T-statistics based on HAC Newey and West (1987) standard errors with Andrews (1991) lag selection are reported in parentheses. The J-test of pricing errors $\left(\alpha^{\prime} V_{\alpha}^{-1} \alpha\right)$ tests if intercepts are jointly equal to zero. Panel B reports cross-sectional asset pricing tests results, namely iterated GMM and FMB. Returns of test assets (carry trade portfolios) are in levels and annualized (multiplied by 12). We report the IMS factor price of risk $(\lambda)$, the cross-sectional $R^{2}$ and the square root of mean-squared errors (RMSE) for each procedure. The standard errors [s.e.] are reported in brackets and based on the Newey-West [NW] approach with optimal lags and Shanken (1992) correction [Sh]. A constant is not included in the second stage of FMB regression. The sample period is January 1985 to December 2014. 
Table 4. Asset Pricing: Two factor model

\begin{tabular}{|c|c|c|c|c|c|c|c|c|c|c|}
\hline \multicolumn{11}{|c|}{ Panel A. Factor Betas } \\
\hline & \multicolumn{5}{|c|}{ All Countries } & \multicolumn{5}{|c|}{ Developed Countries } \\
\hline Portfolio & $\alpha$ & $\beta_{D O L}$ & $\beta_{I M S}$ & $\operatorname{adj} .-R^{2}$ & $\mathrm{~J}$ & $\alpha$ & $\beta_{D O L}$ & $\beta_{I M S}$ & adj.- $-R^{2}$ & $\mathrm{~J}$ \\
\hline \multirow[t]{2}{*}{1} & -0.18 & 0.91 & -0.16 & 65.94 & & -0.05 & 0.92 & -0.34 & 76.34 & \\
\hline & $(-1.77)$ & (12.74) & $(-4.16)$ & & & $(-0.62)$ & (18.05) & $(-8.09)$ & & \\
\hline \multirow[t]{2}{*}{2} & -0.10 & 0.85 & -0.12 & 78.52 & & 0.03 & 0.94 & -0.06 & 81.39 & \\
\hline & $(-1.80)$ & (18.37) & $(-5.84)$ & & & $(0.66)$ & (29.09) & $(-1.89)$ & & \\
\hline \multirow[t]{2}{*}{3} & -0.04 & 1.01 & -0.09 & 79.28 & & -0.08 & 0.95 & 0.06 & 82.49 & \\
\hline & $(-0.67)$ & (23.29) & $(-2.39)$ & & & $(-1.22)$ & (31.44) & $(1.63)$ & & \\
\hline \multirow[t]{2}{*}{4} & -0.04 & 0.98 & 0.00 & 78.98 & & 0.10 & 1.19 & 0.35 & 79.45 & \\
\hline & $(-0.69)$ & (18.21) & $(0.08)$ & & & $(1.31)$ & $(25.11)$ & $(6.79)$ & & \\
\hline \multirow[t]{2}{*}{5} & -0.11 & 1.12 & 0.03 & 78.79 & & & & & & \\
\hline & $(-1.33)$ & $(26.26)$ & $(0.63)$ & & & & & & & \\
\hline \multirow[t]{2}{*}{6} & 0.48 & 1.12 & 0.34 & 66.79 & & & & & & \\
\hline & $(3.83)$ & (16.17) & $(5.40)$ & & & & & & & \\
\hline \multirow{2}{*}{$\begin{array}{r}\text { J-test } \\
\text { (p-value) }\end{array}$} & & & & & 24.48 & & & & & 3.87 \\
\hline & & & & & $(0.00)$ & & & & & $(0.42)$ \\
\hline \multicolumn{11}{|c|}{ Panel B. Risk Prices } \\
\hline & \multicolumn{6}{|c|}{ All Countries } & \multicolumn{4}{|c|}{ Developed Countries } \\
\hline GMM & DOL & IMS & $R^{2}$ & RMSE & & DOL & IMS & $R^{2}$ & RMSE & \\
\hline$\lambda$ & 3.49 & 16.94 & 96.29 & 0.93 & & 3.10 & 6.03 & 96.88 & 0.64 & \\
\hline [s.e.] & {$[1.26]$} & [3.38] & & & & {$[1.48]$} & {$[2.82]$} & & & \\
\hline FMB & DOL & IMS & $R^{2}$ & RMSE & & DOL & IMS & $R^{2}$ & RMSE & \\
\hline$\lambda$ & 3.49 & 17.71 & 96.36 & 0.92 & & 3.10 & 6.09 & 96.88 & 0.64 & \\
\hline$[\mathrm{NW}]$ & [1.33] & [3.59] & & & & [1.53] & {$[2.87]$} & & & \\
\hline [Sh.] & {$[1.35]$} & [3.61] & & & & {$[1.55]$} & {$[2.91]$} & & & \\
\hline
\end{tabular}

Note: The table set up is identical to that in Table 3 with the only exception being that the results are reported for time-series regressions and cross-sectional asset pricing tests based on the two factor model. These factors are: the dollar risk factor (DOL) from Lustig, Roussanov, and Verdelhan (2011) and the IMS (indebted-minus-solvent) factor. The IMS factor is based on a solvency measure (foreign debt-to-GDP) sorts. Returns are monthly and portfolios are rebalanced on an annual basis. Results for the sample of all countries are presented in the left panel and for developed countries in the right panel. Panel A reports estimates for monthly time series regressions of $(\log )$ carry trade excess returns on the intercept, the DOL factor and the IMS factor for each forward discount sorted portfolio. These estimates are: the constant $(\alpha)$ (in percentage points); the DOL factor loading $\left(\beta_{D O L}\right)$; the IMS factor loading $\left(\beta_{I M S}\right)$; and the adjusted- $R^{2}$ (in percentage points). T-statistics based on HAC Newey and West (1987) standard errors with Andrews (1991) lag selection are reported in parentheses. The J-test of pricing errors $\left(\alpha^{\prime} V_{\alpha}^{-1} \alpha\right)$ tests if intercepts are jointly equal to zero. Panel B reports cross-sectional asset pricing tests results, namely iterated GMM and FMB. Returns of test assets (carry trade portfolios) are in levels and annualized (multiplied by 12). We report the factor price of risk $(\lambda)$ for the DOL and the IMS factors, the cross-sectional $R^{2}$ and the square root of mean-squared errors (RMSE) for each procedure. The standard errors [s.e] are reported in brackets and based on Newey-West [NW] approach with optimal lags and Shanken (1992) correction [Sh]. A constant is not included in the second stage of FMB regression. The sample period is January 1985 to December 2014. 
Table 5. Asset pricing: $I M S$ vs. $H M L_{F X}$ and $V O L_{F X}$ risk factors

\begin{tabular}{|c|c|c|c|c|c|c|c|c|c|}
\hline \multicolumn{5}{|c|}{ Panel A. Lustig et. al (2011) model and IMS } & \multicolumn{5}{|c|}{ Panel B. Menkhoff et. al (2012) model and IMS } \\
\hline Factor & $\lambda$ & [s.e.] & $R^{2}$ & RMSE & Factor & $\lambda$ & [s.e.] & $R^{2}$ & RMSE \\
\hline$D O L$ & 3.49 & [0.65] & 96.96 & 0.84 & $D O L$ & 3.88 & [1.35] & 91.97 & 1.49 \\
\hline$H M L_{F X}$ & 10.18 & [1.54] & & & $V O L_{F X}$ & 1.12 & [0.40] & & \\
\hline IMS & 9.95 & [2.69] & & & $I M S$ & 11.72 & [3.15] & & \\
\hline \multicolumn{5}{|c|}{ Panel C. IMS (orth.) and HML } & \multicolumn{5}{|c|}{ Panel D. IMS and HML(orth.) } \\
\hline Factor & $\lambda$ & [s.e.] & $R^{2}$ & RMSE & Factor & $\lambda$ & [s.e.] & $R^{2}$ & RMSE \\
\hline$D O L$ & 3.50 & [0.97] & 96.96 & 0.84 & $D O L$ & 3.49 & {$[0.27]$} & 96.96 & 0.84 \\
\hline$H M L_{F X}$ & 10.18 & [1.04] & & & $H M L_{F X}^{\text {Orth }}$ & 5.22 & [3.39] & & \\
\hline$I M S^{\text {orth. }}$ & 5.41 & {$[0.28]$} & & & $I M S$ & 9.95 & [4.49] & & \\
\hline
\end{tabular}

Note: The table reports the results of the iterated GMM procedure where SDF is linearly defined as in Lustig, Roussanov, and Verdelhan (2011) (Panel A) or in Menkhoff, Sarno, Schmeling, and Schrimpf (2012) (Panel B), but enhanced with the various modifications of the IMS factor. Returns of test assets (six carry trade portfolios) are in levels and annualized (multiplied by 12). We report the factor price of risk $(\lambda)$ for the DOL, the IMS factors and either $H M L_{F X}$ (Panels A, C and D) or $V O L_{F X}\left(\right.$ Panel B), the cross-sectional $R^{2}$ and the square root of meansquared errors (RMSE). In Panels $\mathrm{C}$ the $I M S$ factor is orthogonalized w.r.t. $H M L_{F X}$, and in Panel D we orthogonalize $H M L_{F X}$ w.r.t. IMS. The GMM standard errors [s.e] are reported in brackets. The sample period is January 1985 to December 2014. 
Table 6. Asset Pricing: Sample split

\begin{tabular}{|c|c|c|c|c|c|c|c|c|c|c|}
\hline \multicolumn{11}{|c|}{ Panel A. Factor Betas } \\
\hline & \multicolumn{5}{|c|}{ First half } & \multicolumn{5}{|c|}{ Second half } \\
\hline Portfolio & $\alpha$ & $\beta_{D O L}$ & $\beta_{I M S}$ & adj.- $-R^{2}$ & $\mathrm{~J}$ & $\alpha$ & $\beta_{D O L}$ & $\beta_{I M S}$ & $\operatorname{adj} .-R^{2}$ & J \\
\hline \multirow[t]{2}{*}{1} & -0.24 & 0.94 & -0.17 & 63.72 & & -0.13 & 0.86 & -0.10 & 70.50 & \\
\hline & $(-1.45)$ & $(8.64)$ & $(-3.88)$ & & & $(-1.19)$ & (12.13) & $(-2.39)$ & & \\
\hline \multirow[t]{2}{*}{2} & -0.050 & 0.87 & -0.12 & 79.72 & & -0.16 & 0.81 & -0.10 & 76.73 & \\
\hline & $(-0.58)$ & (13.24) & $(-5.60)$ & & & $(-2.07)$ & (14.07) & $(-3.73)$ & & \\
\hline \multirow[t]{2}{*}{3} & 0.05 & 0.94 & -0.11 & 75.14 & & -0.14 & 1.08 & -0.06 & 84.93 & \\
\hline & $(0.50)$ & (17.06) & $(-2.54)$ & & & $(-2.06)$ & (19.52) & $(-1.49)$ & & \\
\hline \multirow[t]{2}{*}{4} & 0.05 & 0.88 & -0.01 & 71.49 & & -0.14 & 1.11 & -0.03 & 87.57 & \\
\hline & $(0.46)$ & (12.12) & $(-0.37)$ & & & $(-2.24)$ & (18.53) & $(-1.07)$ & & \\
\hline \multirow[t]{2}{*}{5} & 0.02 & 1.17 & 0.07 & 79.22 & & -0.22 & 1.12 & -0.05 & 79.36 & \\
\hline & $(0.19)$ & (17.26) & (1.13) & & & $(-2.05)$ & (20.08) & $(-0.61)$ & & \\
\hline \multirow[t]{2}{*}{6} & 0.18 & 1.20 & 0.35 & 69.23 & & 0.80 & 1.03 & 0.34 & 65.11 & \\
\hline & $(1.32)$ & (14.22) & (5.13) & & & $(3.98)$ & $(9.56)$ & $(3.47)$ & & \\
\hline J-test & & & & & 4.41 & & & & & 26.01 \\
\hline (p-value) & & & & & $0.62)$ & & & & & $(0.00)$ \\
\hline \multicolumn{11}{|c|}{ 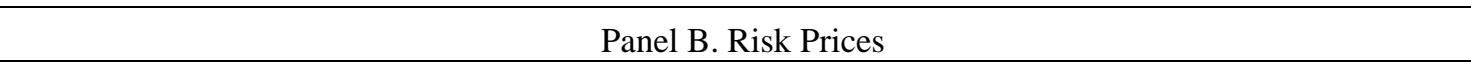 } \\
\hline & \multicolumn{5}{|c|}{ First half } & \multicolumn{5}{|c|}{ Second half } \\
\hline GMM & DOL & IMS & $R^{2}$ & RMSE & & DOL & IMS & $R^{2}$ & RMSE & \\
\hline$\lambda$ & 3.08 & 6.88 & 92.91 & 0.95 & & 3.87 & 27.12 & 96.75 & 1.17 & \\
\hline [s.e.] & [1.86] & [4.86] & & & & {$[1.61]$} & [3.82] & & & \\
\hline FMB & $\mathrm{DOL}$ & IMS & $R^{2}$ & RMSE & & DOL & IMS & $R^{2}$ & RMSE & \\
\hline$\lambda$ & 3.08 & 6.88 & 92.91 & 0.95 & & 3.85 & 32.34 & 98.31 & 0.85 & \\
\hline [NW] & [1.94] & [5.27] & & & & {$[1.82]$} & [4.95] & & & \\
\hline [Sh.] & [1.97] & [5.27] & & & & [1.86] & {$[5.17]$} & & & \\
\hline
\end{tabular}

Note: The table set up is identical to the one in Table 4 with the only exception being that results of time-series regressions and cross-sectional asset pricing tests are reported for the 50/50 time split of the full sample. Results for the first half of the sample (January 1985 to December 1999) are presented in the left panel and for the second half (January 1999 to December 2014) in the right panel. Returns are monthly and portfolios are rebalanced on an annual basis. Panel A reports estimates for monthly time series regressions of (log) carry trade excess returns on the intercept, the DOL factor and the IMS factor for each carry trade portfolio. These estimates are: the constant $(\alpha)$ (in percentage points); the DOL factor loading $\left(\beta_{D O L}\right)$; the IMS factor loading $\left(\beta_{I M S}\right)$; and the adjusted- $R^{2}$ (in percentage points). T-statistics based on HAC Newey and West (1987) standard errors with Andrews (1991) lag selection are reported in parentheses. The J-test of pricing errors $\left(\alpha^{\prime} V_{\alpha}^{-1} \alpha\right)$ tests if intercepts are jointly equal to zero. Panel B reports cross-sectional asset pricing tests results, namely iterated GMM and FMB. Returns of test assets (carry trade portfolios) are in levels and annualized (multiplied by 12). We report the factor price of risk $(\lambda)$ for the DOL and the IMS factors, the cross-sectional $R^{2}$ and the square root of mean-squared errors (RMSE) for each procedure. The standard errors [s.e] are reported in brackets and based on the Newey-West [NW] approach with optimal lags and Shanken (1992) correction [Sh]. A constant is not included in the second stage of FMB regression. 
Table 7. Asset Pricing: Alternative measure of solvency

\begin{tabular}{|c|c|c|c|c|c|c|c|c|c|c|}
\hline \multicolumn{11}{|c|}{ Panel A. Factor Betas } \\
\hline & \multicolumn{5}{|c|}{ All Countries } & \multicolumn{5}{|c|}{ Developed Countries } \\
\hline Portfolio & $\alpha$ & $\beta_{D O L}$ & $\beta_{C X G S}^{I M S}$ & adj. $-R^{2}$ & $\mathrm{~J}$ & $\alpha$ & $\beta_{D O L}$ & $\beta_{C X G S}^{I M S}$ & adj. $-R^{2}$ & $\mathrm{~J}$ \\
\hline \multirow[t]{2}{*}{1} & -0.19 & 0.90 & -0.24 & 70.35 & & -0.06 & 0.94 & -0.35 & 81.09 & \\
\hline & $(-1.94)$ & (13.37) & $(-6.36)$ & & & $(-0.71)$ & (19.93) & $(-10.16)$ & & \\
\hline \multirow[t]{2}{*}{2} & -0.14 & 0.85 & -0.09 & 77.11 & & 0.04 & 0.94 & -0.07 & 81.81 & \\
\hline & $(-2.20)$ & $(17.31)$ & $(-3.78)$ & & & $(0.68)$ & $(27.30)$ & $(-2.56)$ & & \\
\hline \multirow[t]{2}{*}{3} & -0.07 & 1.02 & -0.05 & 78.25 & & -0.08 & 0.95 & 0.06 & 82.82 & \\
\hline & $(-1.04)$ & $(24.00)$ & $(-1.66)$ & & & $(-1.23)$ & $(31.30)$ & $(1.80)$ & & \\
\hline \multirow[t]{2}{*}{4} & -0.06 & 0.99 & 0.01 & 78.68 & & 0.10 & 1.17 & 0.37 & 84.03 & \\
\hline & $(-0.94)$ & (18.11) & $(0.31)$ & & & (1.34) & $(24.50)$ & (7.17) & & \\
\hline \multirow[t]{2}{*}{5} & -0.15 & 1.19 & 0.10 & 77.92 & & & & & & \\
\hline & $(-1.49)$ & $(23.77)$ & $(2.26)$ & & & & & & & \\
\hline \multirow[t]{2}{*}{6} & 0.60 & 1.05 & 0.28 & 58.33 & & & & & & \\
\hline & $(3.77)$ & $(13.15)$ & $(4.69)$ & & & & & & & \\
\hline \multirow{2}{*}{$\begin{array}{r}\text { J-test } \\
\text { (p-value) }\end{array}$} & & & & & 33.27 & & & & & 4.32 \\
\hline & & & & & $(0.00)$ & & & & & $(0.36)$ \\
\hline \multicolumn{11}{|c|}{ Panel B. Risk Prices } \\
\hline & \multicolumn{6}{|c|}{ All Countries } & \multicolumn{4}{|c|}{ Developed Countries } \\
\hline GMM & DOL & $I M S_{\mathrm{CXGS}}$ & $R^{2}$ & RMSE & & DOL & $I M S_{\mathrm{CXGS}}$ & $R^{2}$ & RMSE & \\
\hline$\lambda$ & 3.64 & 17.81 & 86.46 & 1.92 & & 3.10 & 5.89 & 96.89 & 0.64 & \\
\hline [s.e.] & [1.18] & [3.43] & & & & [1.47] & [2.65] & & & \\
\hline FMB & DOL & $I M S_{\mathrm{CXGS}}$ & $R^{2}$ & RMSE & & DOL & $I M S_{\mathrm{CXGS}}$ & $R^{2}$ & RMSE & \\
\hline$\lambda$ & 3.61 & 18.40 & 86.49 & 1.92 & & 3.10 & 5.94 & 96.89 & 0.64 & \\
\hline$[\mathrm{NW}]$ & {$[1.31]$} & [3.72] & & & & [1.53] & [2.74] & & & \\
\hline [Sh.] & {$[1.34]$} & [3.73] & & & & {$[1.55]$} & [2.76] & & & \\
\hline
\end{tabular}

Note: The table reports time series regressions and cross-sectional asset pricing tests results with SDF linearly defined by the dollar risk factor (DOL) and the alternatively specified indebted-minus-solvent risk factor (CAXGS). The CAXGS factor is of a similar nature to the IMS factor, but is based on an alternative solvency measure, which is current account-to-export of goods and services. As before, returns are monthly and portfolios are rebalanced on an annual basis. Results for the sample of all countries are presented in the left panel and for developed countries in the right panel. Panel A reports estimates of monthly time series regressions of (log) carry trade excess returns on the intercept, the DOL factor and the CAXGS factor for each carry portfolio. These estimates are: the constant $(\alpha)$ (in percentage points); the DOL factor loading $\left(\beta_{D O L}\right)$; the CAXGS factor loading $\left(\beta_{\text {CXGS }}\right)$; and the adjusted- $R^{2}$ (in percentage points). T-statistics based on HAC Newey and West (1987) standard errors with Andrews (1991) lag selection are reported in parentheses. A J-test of pricing errors $\left(\alpha^{\prime} V_{\alpha}^{-1} \alpha\right)$ tests if intercepts are jointly equal to zero. Panel B reports cross-sectional asset pricing tests results, namely iterated GMM and FMB. Returns of test assets (carry trade portfolios) are in levels and annualized (multiplied by 12). We report the factor price of risk $(\lambda)$ for the DOL and the CAXGS factors, the cross-sectional $R^{2}$ and the square root of mean-squared errors (RMSE) for each procedure. The standard errors [s.e] are reported in brackets and based on the Newey-West [NW] approach with optimal lags and Shanken (1992) correction [Sh]. A constant is not included in the second stage of FMB regression. The sample period is January 1985 - December 2014. 
Table 8. Asset Pricing: Various information sets

\begin{tabular}{|c|c|c|c|c|c|c|c|c|}
\hline \multicolumn{7}{|c|}{ Factor Betas } & \multicolumn{2}{|c|}{ Risk Prices } \\
\hline \multicolumn{9}{|c|}{ Set A (updated 03/31) } \\
\hline Portfolio & 1 & 2 & 3 & 4 & 5 & 6 & & GMM \\
\hline$\alpha$ & $\begin{array}{c}-0.19 \\
(-1.83)\end{array}$ & $\begin{array}{c}-0.14 \\
(-2.05)\end{array}$ & $\begin{array}{c}0.00 \\
(0.07)\end{array}$ & $\begin{array}{c}0.06 \\
(1.02)\end{array}$ & $\begin{array}{c}-0.15 \\
(-1.48)\end{array}$ & $\begin{array}{c}0.43 \\
(3.51)\end{array}$ & $\lambda_{\mathrm{DOL}}$ & $\begin{array}{c}3.82 \\
{[1.31]}\end{array}$ \\
\hline$\beta_{D O L}$ & $\begin{array}{c}0.80 \\
(9.35)\end{array}$ & $\begin{array}{c}0.94 \\
(16.78)\end{array}$ & $\begin{array}{c}0.99 \\
(24.97)\end{array}$ & $\begin{array}{c}1.02 \\
(23.19)\end{array}$ & $\begin{array}{c}1.19 \\
(23.36)\end{array}$ & $\begin{array}{c}1.07 \\
(18.06)\end{array}$ & $\lambda_{\text {IMS }}$ & $\begin{array}{l}14.73 \\
{[3.49]}\end{array}$ \\
\hline$\beta_{I M S}$ & $\begin{array}{c}-0.21 \\
(-3.77)\end{array}$ & $\begin{array}{c}-0.08 \\
(-2.28)\end{array}$ & $\begin{array}{c}-0.06 \\
(-2.39)\end{array}$ & $\begin{array}{c}-0.05 \\
(-0.86)\end{array}$ & $\begin{array}{c}0.03 \\
(0.85)\end{array}$ & $\begin{array}{c}0.36 \\
(6.15)\end{array}$ & J-test & $\begin{array}{l}52.15 \\
(0.00)\end{array}$ \\
\hline adj. $-R^{2}$ & 58.68 & 74.96 & 84.30 & 79.31 & 78.33 & 67.76 & $R^{2}$ & 92.94 \\
\hline \multicolumn{9}{|c|}{ Set B (updated 06/30) } \\
\hline Portfolio & 1 & 2 & 3 & 4 & 5 & 6 & & GMM \\
\hline$\alpha$ & $\begin{array}{c}-0.17 \\
(-1.90)\end{array}$ & $\begin{array}{c}-0.10 \\
(-1.65)\end{array}$ & $\begin{array}{c}-0.05 \\
(-0.89)\end{array}$ & $\begin{array}{c}-0.05 \\
(-0.89)\end{array}$ & $\begin{array}{c}0.01 \\
(0.16)\end{array}$ & $\begin{array}{c}0.36 \\
(3.23)\end{array}$ & $\lambda_{\mathrm{DOL}}$ & $\begin{array}{c}3.50 \\
{[1.33]}\end{array}$ \\
\hline$\beta_{D O L}$ & $\begin{array}{c}0.89 \\
(11.22)\end{array}$ & $\begin{array}{c}0.84 \\
(16.94)\end{array}$ & $\begin{array}{c}1.04 \\
(23.32)\end{array}$ & $\begin{array}{c}1.02 \\
(18.71)\end{array}$ & $\begin{array}{c}1.06 \\
18.27)\end{array}$ & $\begin{array}{c}1.16 \\
(23.01)\end{array}$ & $\lambda_{\mathrm{IMS}}$ & $\begin{array}{c}9.92 \\
{[2.65]}\end{array}$ \\
\hline$\beta_{I M S}$ & $\begin{array}{c}-0.24 \\
(-6.65)\end{array}$ & $\begin{array}{c}-0.11 \\
(-3.60)\end{array}$ & $\begin{array}{c}-0.05 \\
(-1.24)\end{array}$ & $\begin{array}{c}-0.01 \\
(-0.38)\end{array}$ & $\begin{array}{c}-0.05 \\
(-1.52)\end{array}$ & $\begin{array}{c}0.47 \\
(8.23)\end{array}$ & J-test & $\begin{array}{l}40.45 \\
(0.00)\end{array}$ \\
\hline adj. $-R^{2}$ & 69.05 & 74.82 & 82.77 & 81.57 & 78.01 & 74.20 & $R^{2}$ & 98.98 \\
\hline \multicolumn{9}{|c|}{ Set C (updated 12/31) } \\
\hline Portfolio & 1 & 2 & 3 & 4 & 5 & 6 & & GMM \\
\hline$\alpha$ & $\begin{array}{c}-0.17 \\
(-1.73)\end{array}$ & $\begin{array}{c}-0.09 \\
(-1.48)\end{array}$ & $\begin{array}{c}-0.02 \\
(-0.39)\end{array}$ & $\begin{array}{c}-0.02 \\
(-0.36)\end{array}$ & $\begin{array}{c}-0.02 \\
(-1.37)\end{array}$ & $\begin{array}{c}0.43 \\
(3.29)\end{array}$ & $\lambda_{\mathrm{DOL}}$ & $\begin{array}{c}3.21 \\
{[1.32]}\end{array}$ \\
\hline$\beta_{D O L}$ & $\begin{array}{c}0.89 \\
(11.32)\end{array}$ & $\begin{array}{c}0.83 \\
(17.51)\end{array}$ & $\begin{array}{c}1.03 \\
(23.19)\end{array}$ & $\begin{array}{c}1.00 \\
(17.33)\end{array}$ & $\begin{array}{c}1.12 \\
(24.75)\end{array}$ & $\begin{array}{c}1.13 \\
(14.32)\end{array}$ & $\lambda_{\mathrm{IMS}}$ & $\begin{array}{c}13.94 \\
{[2.96]}\end{array}$ \\
\hline$\beta_{I M S}$ & $\begin{array}{c}-0.20 \\
(-4.22)\end{array}$ & $\begin{array}{c}-0.14 \\
(-5.65)\end{array}$ & $\begin{array}{c}-0.11 \\
(-3.06)\end{array}$ & $\begin{array}{c}-0.02 \\
(-0.62)\end{array}$ & $\begin{array}{c}0.07 \\
(1.23)\end{array}$ & $\begin{array}{c}0.41 \\
(5.43)\end{array}$ & J-test & $\begin{array}{c}55.84 \\
(0.00)\end{array}$ \\
\hline adj. $-R^{2}$ & 64.50 & 77.46 & 79.13 & 78.80 & 78.77 & 67.73 & $R^{2}$ & 94.57 \\
\hline
\end{tabular}

Note: The table reports time series regressions and cross-sectional asset pricing tests results with SDF linearly defined by the dollar risk factor (DOL) and the indebted-minus-solvent risk factor (IMS). As before. returns are monthly and portfolios are rebalanced on an annual basis. but using the macro data for previous year that is available at the end of March (Set A). June (Set B) and December (Set C) of the current year. Carry trade portfolios are updated at the end of each of the above mentioned periods using the previous month's forward discounts. Results for monthly time series regressions of $(\log )$ carry trade excess returns on the intercept. the DOL factor and the IMS factor for each carry portfolio are presented in the left-hand panel. These estimates are: the constant $(\alpha)$ (in percentage points); the DOL factor loading $\left(\beta_{D O L}\right)$; the IMS factor loading $\left(\beta_{\mathrm{IMS}}\right)$; and the adjusted- $R^{2}$ (in percentage points). T-statistics based on HAC Newey and West (1987) standard errors with Andrews (1991) lag selection are reported in parentheses. The right-hand panel reports results of the iterated GMM. Returns of test assets (carry trade portfolios) are in levels and annualized (multiplied by 12). J-test of pricing errors $\left(\alpha^{\prime} V_{\alpha}^{-1} \alpha\right)$ tests if intercepts are jointly equal to zero. We report the factor price of risk $(\lambda)$ for the DOL and the IMS factors. the cross-sectional $R^{2}$. The standard errors [s.e] are reported in brackets and based on Newey-West [NW] approach with optimal lags and $p$-values for the J-test are in parentheses. A constant is not included in the second stage of FMB regression. 

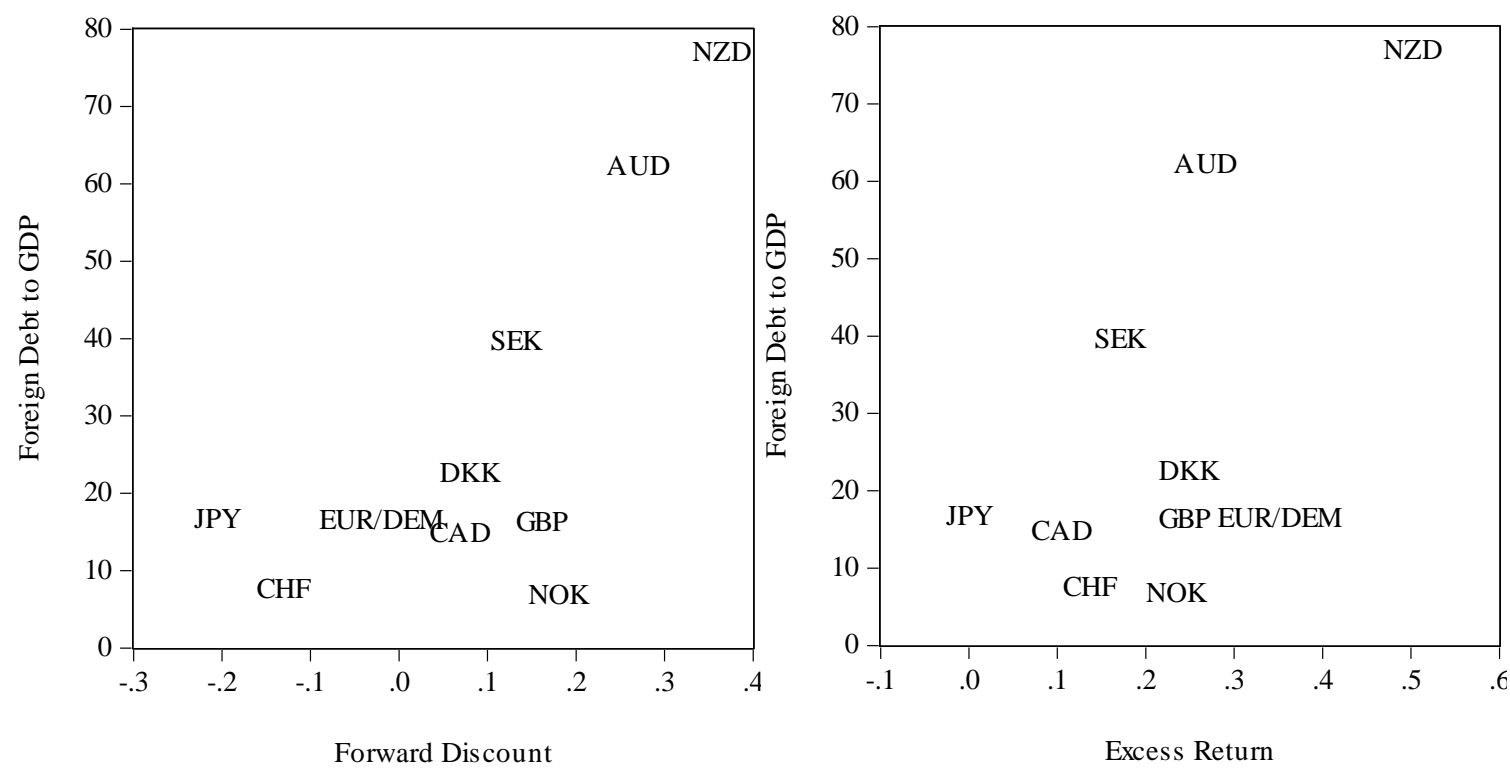

Figure 1. Developed countries and Solvency measure.

Note: The figure plots forward discount and excess return for each country in the developed sample against the corresponding solvency measure. The sample period is January 1985 to December 2014. Pre-1999 data on the German Mark is merged with post-1999 data on the Euro. The solvency measure is defined by the foreign debt to GDP ratio. 


\section{Appendix}

Table A1. Asset Pricing: Solvency sorted test assets

\begin{tabular}{|c|c|c|c|c|c|c|c|c|c|c|}
\hline \multicolumn{11}{|c|}{ Panel A. Factor Betas } \\
\hline & \multicolumn{5}{|c|}{ All Countries } & \multicolumn{5}{|c|}{ Developed Countries } \\
\hline Portfolio & $\alpha$ & $\beta_{D O L}$ & $\beta_{I M S}$ & adj. $-R^{2}$ & J & $\alpha$ & $\beta_{D O L}$ & $\beta_{I M S}$ & adj. $-R^{2}$ & $\mathrm{~J}$ \\
\hline \multirow[t]{2}{*}{1} & -0.06 & 1.17 & -0.31 & 91.51 & & 0.01 & 1.10 & -0.37 & 93.71 & \\
\hline & $(-1.11)$ & $(42.17)$ & $(-13.48)$ & & & $(0.33)$ & $(41.43)$ & $(-18.03)$ & & \\
\hline \multirow[t]{2}{*}{2} & -0.00 & 0.93 & -0.10 & 75.28 & & -0.03 & 0.86 & 0.00 & 75.33 & \\
\hline & $(-0.04)$ & $(15.86)$ & $(-4.00)$ & & & $(-0.36)$ & $(18.74)$ & $(-0.09)$ & & \\
\hline \multirow[t]{2}{*}{3} & -0.03 & 0.76 & -0.03 & 73.81 & & 0.05 & 0.88 & -0.11 & 70.22 & \\
\hline & $(-0.60)$ & $(26.07)$ & $(-1.43)$ & & & $(0.72)$ & $(19.81)$ & $(-2.77)$ & & \\
\hline \multirow[t]{2}{*}{4} & 0.16 & 0.82 & -0.02 & 71.68 & & -0.02 & 1.10 & 0.63 & 94.03 & \\
\hline & $(2.47)$ & $(19.40)$ & $(-0.62)$ & & & $(-0.48)$ & $(45.88)$ & $(31.29)$ & & \\
\hline \multirow[t]{2}{*}{5} & 0.09 & 1.08 & -0.07 & 79.83 & & & & & & \\
\hline & $(0.94)$ & $(22.15)$ & $(-2.24)$ & & & & & & & \\
\hline \multirow[t]{2}{*}{6} & -0.08 & 1.16 & 0.70 & 94.11 & & & & & & \\
\hline & $(-1.59)$ & $(42.56)$ & (30.69) & & & & & & & \\
\hline J-test & & & & & 30.97 & & & & & 34.55 \\
\hline (p-value) & & & & & $(0.00)$ & & & & & $(0.00)$ \\
\hline
\end{tabular}

Panel B. Risk Prices

\begin{tabular}{lcccccccc}
\hline \multicolumn{9}{c}{ All Countries } \\
\hline GMM & DOL & IMS & $R^{2}$ & RMSE & DOL & IMS & $R^{2}$ & RMSE \\
\hline$\lambda$ & 3.91 & 2.58 & 92.33 & 1.07 & 3.21 & 3.42 & 99.11 & 0.33 \\
s.e. & {$[1.32]$} & {$[1.62]$} & & & {$[1.54]$} & {$[1.70]$} & & \\
\hline FMB & DOL & IMS & $R^{2}$ & RMSE & DOL & IMS & $R^{2}$ & RMSE \\
\hline$\lambda$ & 3.65 & 1.64 & 93.51 & 0.99 & 3.15 & 3.26 & 99.17 & 0.32 \\
{$[\mathrm{NW}]$} & {$[1.33]$} & {$[1.88]$} & & & {$[1.54]$} & {$[1.73]$} & & \\
$(\mathrm{Sh})$ & {$[1.36]$} & {$[1.89]$} & & & {$[1.56]$} & {$[1.75]$} & & \\
& & & & & & & & \\
Mean & $\mathbf{3 . 5 3}$ & $\mathbf{2 . 6 4}$ & & & $\mathbf{3 . 0 8}$ & $\mathbf{3 . 8 1}$ & & \\
\hline \hline
\end{tabular}

Note: The table reports time series regressions and cross-sectional asset pricing tests results for the two factor model using a solvency measure (foreign debt to GDP) sorted portfolios as test assets. The risk factors are: the dollar risk factor (DOL) from Lustig. Roussanov. and Verdelhan (2011) and the IMS (indebted-minus-solvent) factor. The IMS factor is based on solvency measure sorts. Returns are monthly and portfolios are rebalanced on an annual basis. Results for the sample of all countries are presented in the left panel and for developed countries in the right panel. Panel A reports estimates for monthly time series regressions of (log) carry trade excess returns on the intercept and the IMS risk factor for each solvency sorted portfolio. These estimates are: the constant $(\alpha)$; the IMS factor loading $\left(\beta_{I M S}\right)$; and the adjusted- $R^{2}$ (in percentage points). T-statistics based on HAC Newey and West (1987) standard errors with Andrews (1991) lag selection are reported in parentheses. A J-test of pricing errors $\left(\alpha^{\prime} V_{\alpha}^{-1} \alpha\right)$ tests if intercepts are jointly equal to zero. Panel B reports cross-sectional asset pricing tests results. namely iterated GMM and FMB. Returns of test assets (carry trade portfolios) are in levels and annualized (multiplied by 12). We report the IMS factor price of risk $(\lambda)$. the cross-sectional $R^{2}$ and the square root of meansquared errors (RMSE) for each procedure. The standard errors [s.e.] are reported in brackets and based on the Newey-West [NW] approach with optimal lags and Shanken (1992) correction [Sh]. A constant is not included in the second stage of FMB regression. The sample period is January 1985 - December 2014. 
Table A2. The log currency returns and the risk factors

\begin{tabular}{|c|c|c|c|c|c|c|c|c|}
\hline \multicolumn{9}{|c|}{ Panel A. Factor Betas } \\
\hline & \multicolumn{4}{|c|}{ All Countries } & \multicolumn{4}{|c|}{ Developed Countries } \\
\hline Portfolio & $\alpha$ & $\beta_{D O L}$ & $\beta_{I M S}$ & $\operatorname{adj} .-R^{2}$ & $\alpha$ & $\beta_{D O L}$ & $\beta_{I M S}$ & $\operatorname{adj} .-R^{2}$ \\
\hline 1 & 0.00 & -0.85 & 0.16 & 67.67 & -0.00 & -0.91 & 0.34 & 76.06 \\
\hline & $(0.01)$ & $(-12.98)$ & $(4.28)$ & & $(-1.14)$ & $(-16.80)$ & $(8.14)$ & \\
\hline 2 & 0.00 & -0.84 & 0.13 & 78.31 & -0.00 & -0.93 & 0.07 & 81.06 \\
\hline & $(0.91)$ & $(-18.16)$ & $(-5.89)$ & & $(-0.43)$ & $(-29.04)$ & $(2.00)$ & \\
\hline 3 & 0.00 & -1.00 & 0.08 & 80.40 & 0.00 & -0.95 & -0.06 & 81.99 \\
\hline & (1.34) & $(-21.80)$ & $(2.43)$ & & $(-0.95)$ & $(-30.25)$ & $(-1.64)$ & \\
\hline 4 & 0.00 & -0.98 & 0.00 & 78.29 & 0.00 & -1.17 & -0.35 & 78.33 \\
\hline & (3.10) & $(-17.70)$ & $(0.07)$ & & $(2.68)$ & $(-22.30)$ & $(-6.63)$ & \\
\hline 5 & 0.00 & -1.12 & -0.02 & 78.10 & & & & \\
\hline & $(4.48)$ & $(-0.02)$ & $(-0.43)$ & & & & & \\
\hline 6 & 0.01 & -1.02 & -0.24 & 65.12 & & & & \\
\hline & (5.57) & $(14.04)$ & $(-3.11)$ & & & & & \\
\hline
\end{tabular}

Note: The table reports estimates for monthly time-series regressions of the logarithmic change in the spot exchange rate for each carry trade portfolio on the currency-specific risk factors. namely. the dollar risk factor (DOL) from Lustig. Roussanov. and Verdelhan (2011) and the IMS (indebted-minus-solvent) factor. The IMS factor is based on the solvency measure (foreign debt to GDP) sorts. Returns are monthly and portfolios are rebalanced on an annual basis. Results for the sample of all countries are presented in the left panel and for developed countries in the right panel. These estimates are: the constant $(\alpha)$; the IMS factor loading $\left(\beta_{I M S}\right)$; and the adjusted- $R^{2}$ (in percentage points). T-statistics based on HAC Newey and West (1987) standard errors with Andrews (1991) lag selection are reported in parentheses. A J-test of pricing errors $\left(\alpha^{\prime} V_{\alpha}^{-1} \alpha\right)$ tests if intercepts are jointly equal to zero. The sample period is January 1985 - December 2014. 